\title{
Review on chemical composition of gluten-free food for celiac people
}

\author{
Antonella Maggio, Santino Orecchio* and Salvatore Barreca \\ Dipartimento di Scienze e Tecnologie Biologiche, Chimiche e Farmaceutiche, Università di Palermo, Viale delle Scienze, I-90128 Palermo, Italy
}

\begin{abstract}
Gluten free food lead to possible nutrient unbalance resulting in improper nutritional quality of diet. The aim of this review is to show and discuss the composition of main components of common gluten free products in order to provide doctors and nutritionists the necessary data to compile balanced diets for users of gluten-free products and to determine their contribution to the daily intake of nutrients and micro elements. Special emphasis has been addressed to metal contents, fatty acid profiles and fibers.

Scopus Library was used to search for articles published and particular attention was focused on literature published from 2007 to 2018 . A total of 68 research papers were taken into considerations. Compared to common food, GF products show deficit for nutrients and, at this regard, a GF-diet was found to be poor in essential metals such as iron, zinc, magnesium and calcium. On another hand, higher content of fatty acids, especially saturated fatty acids, were founded in several GF industrial products, bakery products and cookies. For these reasons, despite the GF-diet is necessary in celiac disease treatment, in order to determine diet quality, the evaluation of nutritional value or concentration of macro and micro nutrients they must be considered.
\end{abstract}

\section{Introduction}

Celiac disease $(\mathrm{CD})$ is a common chronic enteropathy disease which affects approximately $1-2 \%$ of the word population [1]. CD is intolerance for gluten in genetically predisposed individuals and is characterized by an inappropriate immune response of the T-lymphocytes of the small intestines to gluten peptides [2]. In celiac people, ingestion of gluten leads to inflammation and mucosal damage of the small intestine [3]. The typical lesion in the small intestinal epithelium is villous atrophy with crypt hyperplasia, leading to malabsorption of most nutrients such as minerals ( $\mathrm{Fe}, \mathrm{Ca}, \mathrm{Zn}$, etc.) and others essential components (folic acid, fat-soluble and vitamins) [4]. Today, the only available treatment is a lifelong strict gluten-free diet, which leads to restoration of the atrophied intestinal villi. By removing gluten food from the diet of celiac patients will result, in the majority of cases, a normalization of symptoms and cytological and histological parameters [5]. Generally, coeliac people need assistance from a dietician that has no knowledge on mineral contents or fatty acids, proteins, sugars compositions of available gluten-free products, and, for this reason, it is necessary to know the composition of gluten free foods commonly consumed by individuals with celiac disease.

The increasing number of cases of celiac disease consequently favored the production of numerous commercial food products. In several cases, food companies, in order to improve workability of products, use raw materials at low prices, for an example palm and palmist oils [6,7]. Moreover, in the last ten years, there has been increasing interest on gluten-free bakery and breads. A large type of flours and starches (rice, corn, carob, etc.) as well as many ingredients such as gums, enzymes, soybean proteins, and have been used to mimic the viscoelastic properties of gluten and contribute to improve acceptability and shelf life of gluten-free food [8]. Unfortunately, the use of several bad raw materials long-term can cause several health damages.
On another hand, gluten free diet may lead to possible nutrient deficiencies (such as fiber, micro and macro elements, fatty acids, etc). In detail, common ingredients used in of gluten-free foods are starch and flour of corn, potato, tapioca, rice, etc) and, these raw materials can be considered poor of several micro and macro nutrients. Moreover, in several cases, gluten-free foods tend to be high in fat and calories to enhance flavor, texture and appearance [9]. Several authors [10] assert that many gluten-free cereal products, compared with the enriched wheat products contain lower amounts of thiamin, riboflavin, niacin, folate and iron products that they are intended to replace.

Generally, literature report inadequate intakes of fiber, iron, and calcium in $50 \%$ of celiac females studied [11]. To moderate this leak of nutrients, in few cases, flours are fortified with vitamins and minerals, such as B vitamins and iron [12].

Jason [13], analyzing nearly 1200 gluten free foods (Table 1), affirms that these products have a low average proteins content and are carbohydrate-rich. Considering that the used ingredients are often very low in vitamins and minerals, the Jason findings highlight the need of future researches to examine the levels of these nutrients in foods for celiac people. In addition, Jason affirms that results today do not support the contention that gluten free foods are consistently lower in fiber content or that the nutritional quality of these foods are seriously adversely influenced by the addition of saturated fat or sugar.

${ }^{\star}$ Correspondence to: Santino Orecchio, Dipartimento di Scienze e Tecnologie Biologiche, Chimiche e Farmaceutiche, Università di Palermo, Viale delle Scienze, I-90128 Palermo, Italy, Tel: 399123897968; E-mail: santino.orecchio@unipa.it

Key words: gluten-free, food, celiac people, fatty acids, proteins, minerals

Received: December 27, 2018; Accepted: January 21, 2019; Published: January 25,2019 
Table 1. Metal contents in raw materials used for gluten free products

\begin{tabular}{|c|c|c|c|c|c|c|c|c|c|c|c|c|c|c|c|c|c|c|c|}
\hline \multirow{3}{*}{ Ref. } & \multirow{3}{*}{ Sample } & \multicolumn{18}{|c|}{ Element } \\
\hline & & $\mathbf{P}$ & $\mathrm{Ca}$ & $\mathbf{M g}$ & $\mathbf{K}$ & $\mathrm{Na}$ & Mn & $\mathrm{Fe}$ & $\mathbf{N i}$ & $\mathrm{Cu}$ & Zn & $\mathrm{Cr}$ & Co & As & $\mathrm{Se}$ & Cd & Sb & $\mathbf{H g}$ & $\mathbf{P b}$ \\
\hline & & $\mathrm{mg} / \mathrm{g}$ & $\mathrm{mg} / \mathrm{g}$ & $\mathrm{mg} / \mathrm{g}$ & $\mathrm{mg} / \mathrm{g}$ & $\mathrm{mg} / \mathrm{g}$ & $\mathbf{u g} / \mathrm{g}$ & $\mathbf{u g} / \mathrm{g}$ & $\mathbf{u g} / \mathrm{g}$ & $\mathbf{u g} / \mathrm{g}$ & ug/g & $\mathbf{u g} / \mathrm{g}$ & ug/g & ug/g & ug/g & ug/g & $\mathbf{u g} / \mathrm{g}$ & ug/g & $\mathbf{u g} / \mathrm{g}$ \\
\hline$[13]$ & Flour corn & - & 6.10 & 4.70 & 120 & 1000 & - & 1100 & 29 & - & 500 & 2.6 & - & - & 3.2 & - & - & - & - \\
\hline$[55]$ & Flour rice & - & - & - & - & - & 22.5 & 31.2 & 0.7 & 2.4 & 14.9 & 54 & 30.6 & 112 & 117 & 26 & 1.8 & 2.2 & 4.0 \\
\hline$[55]$ & Flour wheat & - & - & - & - & - & 25.9 & 38 & 0.3 & 3.3 & 20.1 & 10 & 12.8 & 11 & 375 & 45 & 4.8 & 0.9 & 3.0 \\
\hline$[55]$ & Other & - & - & - & - & - & 31.7 & 72.4 & 2.3 & 10.3 & 38 & 52 & 108.5 & 13 & 199 & 31 & 5.3 & 0.6 & 8.0 \\
\hline [55] & Whole grain rice & - & - & - & - & - & - & - & - & - & - & - & - & - & - & - & - & - & - \\
\hline$[55]$ & White & - & - & - & - & - & 7.8 & 3.7 & 0.4 & 2.3 & 13.1 & 48 & 9.3 & 94 & 92 & 38 & 2.2 & 1.4 & 19 \\
\hline$[55]$ & Brown & - & - & - & - & - & 28.9 & 11.5 & 0.4 & 3.1 & 22.5 & 18 & 26.4 & 183 & 404 & 27 & 1.7 & 1.8 & 8.0 \\
\hline$[55]$ & Enriched white & - & - & - & - & - & 9.3 & 19.4 & 0.2 & 1.8 & 12.3 & 58 & 12.1 & 177 & 137 & 10.9 & 6.9 & 1.9 & 21 \\
\hline$[23]$ & Teff seed & 4.29 & 1.80 & 1.84 & 4.27 & 0.12 & - & 76.3 & - & - & 36.3 & - & - & - & - & - & - & - & - \\
\hline [23] & Flour & - & - & - & - & - & 18.7 & 7 & - & - & 16.6 & 27 & 56 & 101 & 62 & 16 & - & - & 50 \\
\hline$[19,22]$ & Amaranth & - & 1.80 & 2.88 & - & - & - & 92 & - & - & 16 & - & - & - & - & - & - & - & - \\
\hline$[19,22]$ & Quinoa & - & 0.33 & 2.07 & - & - & - & 55 & - & - & 18 & - & - & - & - & - & - & - & - \\
\hline$[19,22]$ & Buckwheat & - & 0.61 & 2.03 & - & - & - & 47 & - & - & 10 & - & - & - & - & - & - & - & - \\
\hline$[19,22]$ & Wheat & - & 0.35 & 0.96 & - & - & - & 33 & - & - & 12 & - & - & - & - & - & - & - & - \\
\hline [29] & Quinoa & 3.83 & 1.48 & 2.50 & 9.27 & - & - & - & - & 510 & 440 & - & - & - & - & - & - & - & - \\
\hline [29] & Wheat & 4.68 & 0.50 & 1.69 & 5.78 & - & - & - & - & 70 & 470 & - & - & - & - & - & - & - & - \\
\hline [29] & Rice & 1.38 & 0.07 & 0.74 & 1.18 & - & - & - & - & 20 & 60 & - & - & - & - & - & - & - & - \\
\hline [29] & Barley & 5.03 & 0.43 & 1.29 & 5.03 & - & - & - & - & 30 & 350 & - & - & - & - & - & - & - & - \\
\hline [33] & Flour for cakes & - & 9.8 & - & - & - & 0.39 & 9.8 & 0.04 & 0.33 & 6.7 & 0.08 & - & 0.01 & 0.07 & 0.03 & - & - & 0.03 \\
\hline [33] & Flour & - & 2.6 & - & - & - & 1.3 & - & 0.02 & 0.1 & 1.1 & 0.02 & - & 0.09 & 0.07 & 0.03 & - & - & 0.01 \\
\hline [39] & Teff & - & 0.79 & - & - & - & - & 800 & - & - & 20.2 & - & - & - & - & - & - & - & - \\
\hline [54] & Teff flour & - & - & - & - & - & - & - & - & - & & - & - & - & 0.12 & - & - & - & - \\
\hline
\end{tabular}

In two researches, authors [14,15] affirm that the gluten free diets of children and adults are unbalanced, with a appreciably higher protein and fat content. Bardella [15] founds that the diets of adult celiac people furnish lower percentage of energy as carbohydrates compared to that of the non-celiac subjects.

Several studies [16] conducted in the United States found that the abduction of iron, calcium and fiber of the celiac patients is of concern, in particular among female subjects, moreover, Netherlands [17] researches on 111 celiac peoples revealed that, mean intakes of fiber and iron were significantly lower than Dutch recommendations (DRDA) but comparable with the effective Dutch population intakes while saturated fat intake significantly higher.

In celiac diet, two of the most important sources of essential elements is representing from rice, corn and their derivatives. Rice flour contain about $0.04 \%$ ashes, $0.21 \%$ lipids and $10.7 \%$ proteins. Corn flour contains $0.33 \%$ ashes and $7.50 \%$ proteins. In several cases, field bean semolina (Vicia faba) is used in the gluten free food production that contains $0.08 \%$ ashes, $1.08 \%$ lipids, $30.0 \%$ proteins [18].

Recently, pseudo cereals are used in the preparation of gluten free food. A pseudo cereal is defined as any plant that does not belong to the grass family but produces fruits and seeds used as flour for bread and other staple foods. The preeminent pseudo cereals known so far are grain amaranth (Amaranth caudatus, Amaranth cruentus, Amaranth hypochondriacus), quinoa (Chenopodium quinoa), and buckwheat (Fagopyrum esculentum).

The better nutritional properties of pseudo cereals are well known [19], having higher protein percentages than wheat, and constituting a good source of calcium, magnesium and iron. Consequentially, in several cases, pseudo cereals constitute a valid alternative to common gluten-containing grains, add variety and improve nutritional quality of gluten free food.
Protein content in amaranth and quinoa (Table 2) [19] is generally higher than in cereals containing gluten such as wheat $[20,21]$ and is usually highest in amaranth followed by quinoa and buckwheat.

In pseudocereals the protein bioavailability is high, and the amino acid composition is well balanced, with a high content of essential amino acids, and is higher compared to that of cereals containing gluten [19].

Amaranth, quinoa and buckwheat represent good sources of fiber; in buckwheat seeds the content is significantly higher than that of amaranth and quinoa, which have fiber levels comparable to those of common cereals [22].

Teff is a gluten free grain [23] gaining attractiveness due to its positive nutritional properties [24]. The teff flour is rich in fiber due to the incorporate of the bran components. It is also a source of bioactive compounds such as polyphenols [25].

Despite the great rise in consumption of gluten free foods, there is a lack of evaluation of their composition and nutritional profile and how they compare foods containing gluten. Another important issue in environmental and food quality regard to pollution from organic or inorganic substances, because many of these substances are not degradable and can be bioaccumulate in food chain [26,27]. Food and Agriculture Organization of the United Nations (FAO) has discussed the tolerable intake for several food contaminants, including toxic metals as As, $\mathrm{Cd}$ and $\mathrm{Pb}$ (FAO, 2010). These microelements can be founded in celiac food and their detectable can by scripted by two different origins. The first one depends on the use of massive use of pesticides, the second from possible release from raw materials employed during food manufacturing.

The aim of this review is to show the chemical compositions and discuss the nutritional qualities of GF products in order to provide doctors and nutritionists the necessary data to compile balanced diets for users of gluten-free products and to determine their contribution to the daily intake of nutrients and micro elements. Special emphasis 
Table 2. Macro compounds in raw materials and products

\begin{tabular}{|c|c|c|c|c|c|c|c|c|}
\hline \multirow[t]{2}{*}{ Reference } & \multirow[t]{2}{*}{ Sample } & Fatty acid & $\begin{array}{l}\text { Saturated } \\
\text { fatty acids }\end{array}$ & $\begin{array}{l}\text { Unsatured } \\
\text { fatty acids }\end{array}$ & Sugar & Protein & Fiber & Carboydrates \\
\hline & & $\mathrm{ug} / \mathrm{g}$ & $\mathbf{u g} / \mathrm{g}$ & $\mathrm{ug} / \mathrm{g}$ & ug/g & ug/g & $\mathbf{u g} / \mathrm{g}$ & $\mathbf{u g} / \mathrm{g}$ \\
\hline [13] & Flour corn & 49000 & - & 800 & - & 110000 & - & - \\
\hline [29] & Quinoa & 63000 & - & - & - & 165000 & 3800 & 690000 \\
\hline [29] & Barley & 19000 & - & - & - & 108000 & 44000 & 807000 \\
\hline [29] & Maize & 47000 & - & - & - & 102000 & 23000 & 810000 \\
\hline [29] & Rice & 22000 & - & - & - & 76000 & 64000 & 804000 \\
\hline [29] & Wheat & 23000 & - & - & - & 143000 & 28000 & 784000 \\
\hline [29] & Oat & 52000 & - & - & - & 116000 & 104000 & 698000 \\
\hline [29] & Rye & 18000 & - & - & - & 134000 & 26000 & 801000 \\
\hline [29] & Bean & 11000 & - & - & - & 280000 & 50000 & 612000 \\
\hline [29] & Lupine & 70000 & - & - & - & 391000 & 146000 & 353000 \\
\hline [29] & Soya & 189000 & - & - & - & 361000 & 56000 & 341000 \\
\hline$[23]$ & Teff seed & 23800 & 44900 & 16600 & 18400 & 133000 & 80000 & 730000 \\
\hline$[19,22]$ & Amaranth & 57000 & - & - & - & 165000 & 206000 & - \\
\hline$[19,22]$ & Quinoa & 52000 & - & - & - & 145000 & 142000 & - \\
\hline$[19,22]$ & Buckwheat & 21000 & - & - & - & 125000 & 295000 & - \\
\hline [28] & Amaranth & 50000 & - & - & - & 110000 & 135700 & - \\
\hline$[28]$ & Buckwheat & 25200 & - & - & - & 130700 & 119400 & - \\
\hline [28] & Quinoa & 34400 & - & - & - & 113200 & 145000 & - \\
\hline$[32]$ & Bread & 110500 & - & - & - & 48300 & - & 811800 \\
\hline
\end{tabular}

has been addressed to metal contents, fatty acid profiles, fibers and vitamins.

\section{Materials and methods}

In the last 10 years, documents concerning to gluten free aspects are increasing (Figures 1A-1C). Most of studies concerning to gluten free food, were conducted by US researchers, on another hand, Italy was the second country in term of report produced. At July 2018, literature reporting gluten free as key word shows 6627 documents and only 466 documents are relative at chemistry field. In this context, was necessary to focused attention concerning to several aspect regarding food nutrients in gluten free.

The researches in literature were performed by used the key words gluten free nutrients using Scopus as search engine. From the search resulted 58 articles and only 23 are related to nutritional aspects, published from 2007 to spring 2018. The last were considered for the purpose of this review. Other relevant papers concerning to food quality and their chemical analyses were considerate.

\section{Main components in celiac food}

\section{Carbohydrates}

Starch, the main biopolymeric constituents of plants (grains, tubers and seeds), is the major source of physiological energy in the human diet and accordingly it is classified in general as an available carbohydrate. Some authors $[28,29]$ affirms that in the quinoa, carbohydrates ranges from $67-74 \%$ and the amylose content is about $11 \%$ which is lower than in cereals. Other carbohydrates are in small amounts: monosaccharide's (2\%), disaccharides (2.3\%), crude fiber (2.5-3.9\%) and pentosans (2.93.6\%) [30,31]. María Estela Matos [8] established that gluten-free breads show a high contribution to the carbohydrate dietary reference intake (Table 2), moreover, starch is the most important component of teff grain [23] and may amount up to over $70 \%$ of the dry weight.

\section{Macroelements}

In food, metals and other elements [32-35] can be founded by naturally source or can enter as the result of human activities such as industrial and agricultural processes. The macro elements are very important in several biochemical processes and play a fundamental role in human homeostasis [36]. The content of some minerals in amaranth, quinoa, buckwheat and teff, determinate by several authors, are shown in Table 1 [37]. High calcium content in amaranth seeds were founded, and about teff grain [23], calcium and magnesium have similar concentration (1800 and $1840 \mathrm{mg} \mathrm{Kg}^{-1}$ respectively), similarly, potassium and phosphorous content are 4270 and $4290 \mathrm{mg}$ $\mathrm{Kg}^{-1}$ respectively. Teff seeds contain $120 \mathrm{mg} \mathrm{Kg}^{-1}$ of sodium. Baye et al. [38] showed that the Ca contents of whole grain teff are $788 \mathrm{mg}$ $\mathrm{Kg}^{-1}$. Moreover, numerous researchers have also highlighted the high minerals content of pseudocereals [19-21,38].

In a paper [39] researchers report the results for the quantification of $\mathrm{K}, \mathrm{Li}, \mathrm{Sr}, \mathrm{Na}, \mathrm{Ca}, \mathrm{Mg}$ and $\mathrm{Al}$ in seventeen gluten-free food (Table 3). Considering all analyzed food, potassium ranged from 14 to $3747 \mathrm{mg}$ $\mathrm{kg}^{-1}$. The highest contents were found by us in a flour for cakes (3747 $\left.\mathrm{mg} \mathrm{kg}{ }^{-1}\right)$, crouton $\left(2479 \mathrm{mg} \mathrm{kg}^{-1}\right.$ ) and in the two local bread samples (1327 and $1082 \mathrm{mg} \mathrm{kg}^{-1}$ ). The mean $\mathrm{K}$ concentration was $716 \mathrm{mg} \mathrm{kg}^{-1}$ and is very lower those measured in Hispanic products that showed $\mathrm{K}$ concentration in the interval 4000 and $5000 \mathrm{mg} \mathrm{kg}^{-1}$ [40-42].

The sodium content of the gluten free food samples ranged from 306 to $12315 \mathrm{mg} \mathrm{kg}^{-1}$ with average of $3015 \mathrm{mg} \mathrm{kg}^{-1}$ and, the highest sodium levels were measured in three bread samples. The sodium concentrations in the analyzed samples are very high, for example the mean $\mathrm{Na}$ concentration in some Hispanic wheat cultivars varied significantly between 41.0 and $273 \mathrm{mg} \mathrm{kg}^{-1}$ [43]. The concentration of calcium in samples ranged from 5 to $1682 \mathrm{mg} \mathrm{kg}^{-1}$. The mean value was $413 \mathrm{mg} \mathrm{kg}^{-1}$. The highest values were detected in the Local bread (1682 $\left.\mathrm{mg} \mathrm{kg}^{-1}\right)$, Flour for cake $\left(1658 \mathrm{mg} \mathrm{kg}^{-1}\right)$ and Biscuit $\left(1288 \mathrm{mg} \mathrm{kg}^{-1}\right)$, while the lowest concentrations were found in two pasta samples. Magnesium content was in the range $30-1207 \mathrm{mg} \mathrm{kg}^{-1}$. The mean value was $333 \mathrm{mg}$ $\mathrm{kg}^{-1}$. The highest values were detected in the of breadsticks (1207 mg $\left.\mathrm{kg}^{-1}\right)$ and flour for cakes $\left(813 \mathrm{mg} \mathrm{kg}^{-1}\right)$.

Considering the average concentrations of the elements analyzed, excluding lithium, authors concluded that they are inadequate if compared with the recommended daily intake by international 


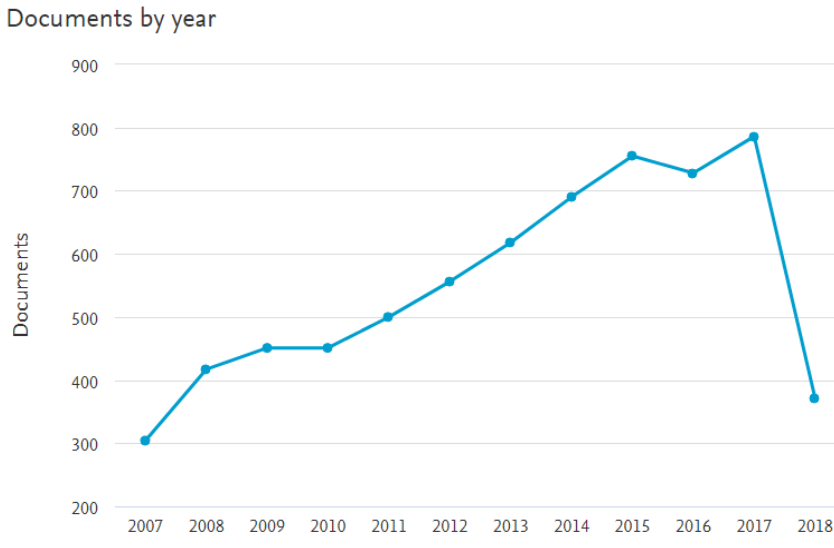

Documents by country or territory

Compare the document counts for up to 15 countries/territories

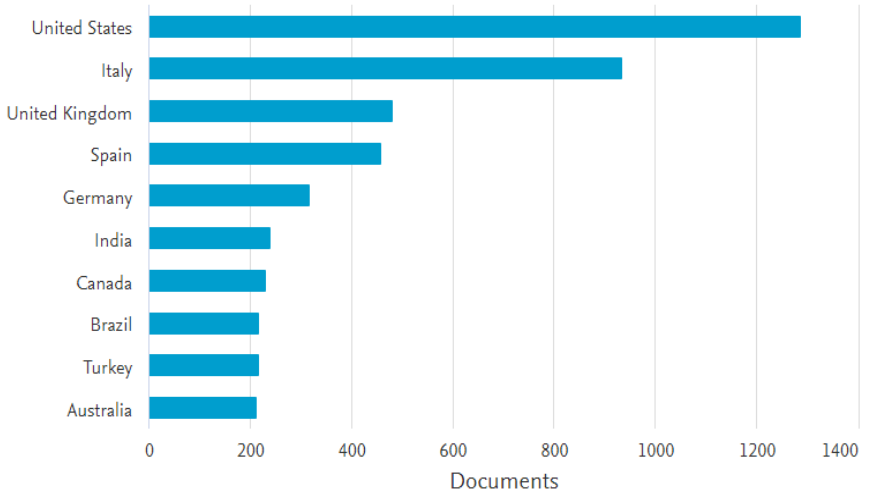

Documents by subject area

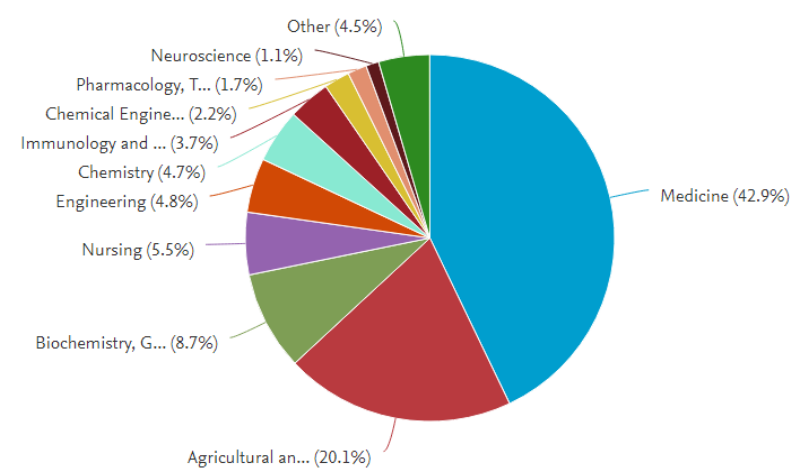

Figure 1. (A) Number of documents concerning to gluten free food from 2007 to 2017; (B) Number of documents produced in several nations concerning to gluten free food from 2007 to 2017; (C) Percentages of studied on gluten free food in several scientific fields from 2007 to 2017

organisms [40], providing only from 1.5 to $20 \%$ of the RDI for the essential metals. In particular, considering that many celiac people consume small quantities of potassium which contribute to regulate blood pressure and prevent hypertension. The tolerable upper level intake is exceeded by consuming more than 200 grams of gluten free bread during a day.

Generally, analyses of food were carried out by four steps; sampling, homogenization, mineralization and analyses. Concerning the quantifications of micro and macro constituents of gluten food matrices, the analyst often has to determine the characteristics of a large quantity of product. Theoretically, the chemist or biologist it should to analyze every part of the material to obtain accurate measures of the property of interest, but, considering practical and economical aspects, this is impossible. At this regard, analyst carry out the analyses on a representative sample and to extend results to all the lot of food. Homogenization is part of the sample preparation procedure and includes mixing and blending of the sample, particle size reduction, and mass reduction.

Literature reported several methods able to mineralize food samples. The most used analytical technique employs sample digestion in a microwave oven by means of $\mathrm{HNO}_{3}(63 \%)$ and $\mathrm{H}_{2} \mathrm{O}_{2}(30 \%)$. Regarding to determination aspects, at present, official methods for the analysis of micro and macro elements content in food matrices can conducted by several instrumental and analytical techniques as reported in Table 4. Based on data reported in Table 4, the choice of method depends on several aspects, from metals to concentration levels in sample.

\section{Microelements}

The heavy metals of particular concern in relation to harmful effects on health are mercury, lead, cadmium, tin and arsenic. The toxicity of these metals can be expressed by acute or chronic, depending to the fact that they accumulate in biological tissues, for a process known as bioaccumulation. This process of bioaccumulation occurs in all living organisms as a result of exposure to metals in food and the environment and includes biomagnifications processes. On another hand, high levels of several metals, due to pollutant contamination, release during manufacturing process and food

Table 3. Macro-element contents in traditional gluten free food [40]

\begin{tabular}{|l|c|c|c|c|c|c|c|}
\hline Sample & $\mathbf{K}$ & $\mathbf{L i}$ & $\mathbf{S r}$ & $\mathbf{N a}$ & $\mathbf{C a}$ & $\mathbf{M g}$ & $\mathbf{A l}$ \\
\cline { 2 - 7 } & $\mathbf{u g} / \mathbf{g}$ & $\mathbf{u g} / \mathbf{g}$ & $\mathbf{u g} / \mathbf{g}$ & $\mathbf{u g} / \mathbf{g}$ & $\mathbf{u g} / \mathbf{g}$ & $\mathbf{u g} / \mathbf{g}$ & $\mathbf{u g} / \mathbf{g}$ \\
\hline Pasta & 250 & 3.0 & 6.6 & 1205 & 5 & 102 & 21 \\
\hline Noodles & 331 & 19 & 2.5 & 409 & 133 & 423 & 0.8 \\
\hline Flour & 208 & 2.8 & 6.2 & 905 & 57 & 86 & 16 \\
\hline Biscuits & 635 & 2.8 & 6.1 & 1986 & 69 & 280 & 18 \\
\hline Pasta fusilli & 386 & 8.0 & 0.2 & 306 & 106 & 359 & 0.6 \\
\hline Pasta linguine & 611 & 2.9 & 6.3 & 923 & 5 & 207 & 19 \\
\hline Egg noodles & 211 & 15 & 102 & 793 & 272 & 373 & 1.5 \\
\hline Finger biscuits & 109 & 43 & 4.5 & 1136 & 340 & 291 & 1.7 \\
\hline Buckwheat biscuits & 1238 & 2.7 & 6.0 & 4172 & 105 & 495 & 17 \\
\hline Croutons & 14 & 4.5 & 78 & 808 & 265 & 256 & 1.3 \\
\hline Rice noodles & 131 & 2.8 & 6.3 & 682 & 237 & 224 & 9.5 \\
\hline Couscous & 940 & 2.6 & 5.8 & 838 & 100 & 247 & 18 \\
\hline Corn couscous & 905 & 2.7 & 48 & 874 & 196 & 273 & 16 \\
\hline Flour for cakes & 3747 & 2.8 & 6.2 & 5427 & 1658 & 813 & 10 \\
\hline Lasagna & 1171 & 2.8 & 6.2 & 4071 & 1098 & 210 & 14 \\
\hline Corn flakes & 855 & 2.7 & 6.0 & 5245 & 123 & 160 & 1.0 \\
\hline Dietetic biscuits & 73 & 9.1 & 12 & 909 & 826 & 231 & 1.0 \\
\hline Breadsticks & 322 & 68 & 3.5 & 3209 & 374 & 1207 & 1.5 \\
\hline Local bread B. & 1327 & 5.8 & 19 & 10383 & 1682 & 317 & 12 \\
\hline Local bread P. & 1082 & 2.8 & 6.2 & 12315 & 490 & 308 & 13 \\
\hline Corn flakes & 855 & 2.7 & 6.0 & 5245 & 123 & 160 & 17 \\
\hline Shortbread & 72 & 25 & 3.5 & 792 & 264 & 279 & 1.0 \\
\hline Biscuits & 33 & 7.7 & 2.0 & 382 & 1288 & 436 & 1.4 \\
\hline Butter cookies & 42 & 15 & 56 & 1134 & 40 & 314 & 1.2 \\
\hline Croutons & 2479 & 248 & 36 & 5816 & 637 & 441 & 13 \\
\hline Egg biscuits & 195 & 40 & 3.9 & 1070 & 297 & 30 & 12 \\
\hline Industrial bread & 1115 & 2.9 & 13 & 10520 & 361 & 456 & 23 \\
\hline
\end{tabular}


packaging, can cause health damage because can be considered as interference with essential metals.

Trace amounts of some metals, manganese, copper, and zinc are essential micro nutrients and have a variety of biochemical functions in all living organisms. For example, copper, is present in enzymes and proteins that protecting the body from free radicals [44]. On another hand, these elements can be considered as toxic when taken in excess and some minerals may constitute a potential health risk if consumed above the tolerable upper in-take levels over extended periods. Examples of these are iodine, lead, arsenic, cadmium and mercury poisoning. For other minerals, the negative effects are less hazardous, producing e.g. gastrointestinal problems. For non-essential elements exposures are undesirable, but acceptable levels are determined by the World Health Organization (WHO) and other international authorities $[40,45,46]$. Indeed, since rice-based foods are widely consumed by celiac people, the exposure to non-essential elements such as arsenic, cadmium and lead is a global concern [47-50].

A study on whole grain teff showed that the Fe and $\mathrm{Zn}$ contents are 316 and $23.1 \mathrm{mg} \mathrm{Kg}^{-1}$ (dry basis), respectively [38]. The total iron content $\left(76.3 \mathrm{mg} \mathrm{Kg}^{-1}\right)$ is high if compared with other microelements, is reduced (about 50\%) by washing. Another research [23] shows that Mn and $\mathrm{Cu}$ contents are higher compared to that of other Ethiopian foods such (maize, wheat, etc.) [51,52]. Rayman [52] quantified selenium in several commercial gluten free products on the European Union market because of its health effects on health. In particular, teff flour contained $120 \mu \mathrm{g} \mathrm{Kg}^{-1}$ of selenium which results higher than that of the other common flours (14-47 $\mu \mathrm{g} \mathrm{Kg}^{-1}$ ) but lower than that of oat flour $\left(235 \mu \mathrm{g} \mathrm{Kg}^{-1}\right)$. A pasta containing Teff, shows a higher Selenium content $\left(90 \mu \mathrm{g} \mathrm{Kg}^{-1}\right)$ compared to other pasta samples (17 and $\left.25 \mu \mathrm{g} \mathrm{Kg}^{-1}\right)$ [52].

Punshon [53] analyzing sixty-seven gluten free food products established that the total arsenic concentration in whole grain rice, rice flour and processed foods containing rice was significantly higher (94000-183000 $\mu \mathrm{g} \mathrm{Kg}^{-1}$ ) than non-rice flours and processed foods based on other grains (11000-18000 $\left.\mu \mathrm{g} \mathrm{Kg}^{-1}\right)$. This in good agreement to other researches on rice and rice products [54]. The same authors affirmed that rice and rice-based products were significantly lower in iron, nickel, copper, zinc and cobalt compared to wheat flours and food products and the other (rice-free) gluten free flours. Other microelements (Mn, $\mathrm{Fe}, \mathrm{Cu}, \mathrm{Zn}, \mathrm{Cr}, \mathrm{Co}, \mathrm{Se}, \mathrm{Sb}$ and $\mathrm{Pb}$ ) concentrations determined by same authors are shown in Table 5. Moreover, literature [32] affirms that $\mathrm{Hg}$ concentrations in gluten free food are lower $4 \mu \mathrm{g} \mathrm{Kg}{ }^{-1}$, concentration that is much lower than that of fish and seafood, which is generally the major source of mercury to diet. On the contrary, instead, cadmium concentrations (10900-38000 $\mathrm{g} \mathrm{Kg}^{-1}$ ) are considerably lower in rice based prepared foods compared to foods containing other grains (31000-52000 $\mu \mathrm{g} \mathrm{Kg}^{-1}$ ).

The aluminum content quantified [39] in seventeen glutenfree food samples ranged from 0.6 to $23 \mathrm{mg} \mathrm{kg}^{-1}$ with average of 10 $\mathrm{mg} \mathrm{kg}^{-1}$ and is in agreement to those $\left(0.4-13 \mathrm{mg} \mathrm{kg}^{-1}\right)$ determined by several authors $[55,56]$ in cereals. In this case, the highest $\mathrm{Al}$ levels were measured in two pasta samples. Considering that $\mathrm{Al}$ additives are contained in specific processed foods, contrary to our expectations, the lower concentrations (about $1 \mathrm{mg} \mathrm{kg}^{-1}$ ) were found in some that generally, in foods with gluten, contain additives. $\mathrm{NaAl}_{3} \mathrm{H}_{14}\left(\mathrm{PO}_{4}\right)_{8}$ is used in the food industry as a leavening agent in baked goods and $\mathrm{Na}_{8} \mathrm{Al}_{2} \mathrm{OH}_{2}\left(\mathrm{PO}_{4}\right)_{4}$ as an emulsifying agent [57]. The concentrations of $\mathrm{Al}$ in convenience and fast foods analyzed by some researches [58] ranged from 0.85 to $38 \mathrm{mg} \mathrm{kg}^{-1}$, (refereed to fresh weight of the edible portion) are higher than gluten free food. In food, aluminum may be: a natural contaminant of vegetal and animal ingredients; a contaminant of industrial food processing; contained in additives; released from kitchenware used for food preparation and/or serving stocking and packaging food materials.

Table 4. Analytical techniques used in metals analyses in food

\begin{tabular}{|l|l|c|c|}
\hline Analytical techniques & Metal analyzed & \multicolumn{1}{c|}{$\begin{array}{c}\text { Linear range } \\
\boldsymbol{\mu g ~ K g - 1}\end{array}$} & $1000-100000$ \\
\hline Flame atomic adsorption & $\begin{array}{l}\text { Alkaline and alkaline } \\
\text { earth metals }\end{array}$ & $1-5$ \\
\hline Furnace atomic adsorption & $\begin{array}{l}\text { Alkaline, alkaline earth } \\
\text { and transition metal }\end{array}$ & $134]$ \\
\hline $\begin{array}{l}\text { Plasma atomic emission inductively } \\
\text { coupled spectroscopy (ICP-OES) }\end{array}$ & $\begin{array}{l}\text { All metals whit some } \\
\text { exceptions }\end{array}$ & $1-200$ \\
\hline $\begin{array}{l}\text { Inductively coupled plasma-time } \\
\text { of flight-mass spectrometry }\end{array}$ & All metals & $1-500$ \\
\hline Electro-analytical techniques & $\begin{array}{l}\text { All metals or substance that } \\
\text { can be oxidized or reduced }\end{array}$ & {$[36]$} \\
\hline
\end{tabular}

Table 5. Microelement contents and total fatty acids in several gluten free food

\begin{tabular}{|c|c|c|c|c|c|c|c|c|c|c|c|c|c|c|c|c|}
\hline \multirow{3}{*}{ Ref. } & \multirow{3}{*}{\begin{tabular}{|l|} 
Samples \\
Prepared foods e pasta
\end{tabular}} & \multirow{3}{*}{$\begin{array}{l}\text { Salts } \\
\mathrm{ug} / \mathrm{g}\end{array}$} & \multicolumn{13}{|c|}{ Metal } & \multirow{3}{*}{$\begin{array}{c}\text { Total fatty acid } \\
\text { ug/g }\end{array}$} \\
\hline & & & Mn & $\mathrm{Fe}$ & $\mathrm{Ni}$ & $\mathbf{C u}$ & $\mathrm{Zn}$ & $\mathrm{Cr}$ & Co & As & $\mathrm{Se}$ & Cd & Sb & $\mathrm{Hg}$ & $\mathbf{P b}$ & \\
\hline & & & $\mathrm{ug} / \mathrm{g}$ & ug/g & $\mathrm{ug} / \mathrm{g}$ & $\mathrm{ug} / \mathrm{g}$ & $\mathrm{ug} / \mathrm{g}$ & $\mathrm{ug} / \mathrm{g}$ & $\mathrm{ug} / \mathrm{g}$ & $\mathrm{ug} / \mathrm{g}$ & ug/g & $u g / g$ & $\mathrm{ug} / \mathrm{g}$ & ug/g & $\mathrm{ug} / \mathrm{g}$ & \\
\hline [55] & Rice & - & 20.1 & 13.3 & 0.4 & 2 & 14.3 & 189 & 23.5 & 141 & 115 & 15.9 & 2.9 & 3.4 & 22 & - \\
\hline [55] & No rice & - & 13.9 & 26.1 & 0.2 & 3.4 & 20.9 & 111 & 6.7 & 15 & 340 & 52.4 & 1.7 & 1 & 7 & - \\
\hline [55] & Rice & - & 17.9 & 14 & 0.3 & 2.2 & 15 & 108 & 19.3 & 147 & 114 & 21.3 & 3.3 & 2.5 & 18 & - \\
\hline [55] & Other & - & 33.1 & 70.7 & 2.4 & 10.4 & 38.1 & 55 & 113.8 & 13 & 207 & 31.5 & 5.2 & 1.7 & 1 & - \\
\hline [2] & Snacks & 19400 & - & - & - & - & - & - & - & - & - & - & - & - & - & 22470 \\
\hline [2] & Fast food & 14600 & - & - & - & - & - & - & - & - & - & - & - & - & - & 11660 \\
\hline$[2]$ & Nuts and oilseed & 8300 & - & - & - & - & - & - & - & - & - & - & - & - & - & 45620 \\
\hline [2] & Cereal products & 4300 & - & - & - & - & - & - & - & - & - & - & - & - & - & 11770 \\
\hline$[2]$ & Sauces & 19700 & - & - & - & - & - & - & - & - & - & - & - & - & - & 29910 \\
\hline$[2]$ & Potato products & 11600 & - & - & - & - & - & - & - & - & - & - & - & - & - & 25580 \\
\hline$[23]$ & Pasta & - & 6.4 & 6.1 & - & 2 & 9.9 & 41 & 19 & 94 & 55 & 14 & - & - & 55 & - \\
\hline
\end{tabular}


The concentrations of seventeen microelements (As, Ba, Cd, Co, $\mathrm{Cr}, \mathrm{Cu}, \mathrm{Fe}, \mathrm{Hg}, \mathrm{Mn}, \mathrm{Mo}, \mathrm{Ni}, \mathrm{Pb}, \mathrm{Sb}, \mathrm{Se}, \mathrm{Sn}, \mathrm{V}$ and $\mathrm{Zn}$ were quantified by Orecchio [32] in twenty-seven samples (Table 6) of gluten-free products (pasta, biscuits, flours, etc.) produced in Italy and collected in 2013 from markets and pharmacies in Palermo (Italy). Inductively coupled plasma mass spectrometry technique (ICP-MS) was used to quantify all the analytes. The highest arsenic and molybdenum concentrations were measured in Rice Noodle from China $(0.088$ and $0.47 \mathrm{mg} \mathrm{kg}^{-1}$ respectively). The highest concentrations of some metals $(\mathrm{Cu}, \mathrm{Ba}, \mathrm{Cd}, \mathrm{Pb}, \mathrm{Hg}, \mathrm{Sr}$ and $\mathrm{V})$ were found in bread and breadstick samples produced in different bakeries located at Palermo. The analytical results indicate a large variability between samples with respect to metal concentrations, which could be due to the proportion of different ingredients used in the food compositions and to different levels of contaminants in the production laboratories. In particular, foods analyzed contain levels of hazardous trace elements under the limits tolerated by the law and the contribution of the foods to the daily intake of all the elements analyzed remains under the recommended levels by international organisms. Considering the average concentrations of some microelements found in this study, authors concluded that they are inadequate if compared with the recommended daily intake by international organisms, providing from 1.1 to $53 \%$ of the RDI for the essential metals. These conclusions are in good agreement to some authors affirming that commercial gluten-free cereal foods, made of refined flours or starches, are of lower nutritional value compared to their wheat counterparts.

\section{Fatty acids}

Fatty acids play important roles in human activities. A large variety of fatty acids has been founded in the diet of humans, in the bloodstream and in cells and tissues. Fatty acids, in addition to be energy sources, represent membrane constituents. Indeed, they have biological activities those explicate actions on tissue metabolism, function, and responsiveness to hormonal and other signals. Through several effects, fatty acids influence health, wellbeing, and disease risk. In this context, food characterization regarding by fatty acids, represents an important tool in order to prevent some health effect. For example, Polyunsaturated Fatty Acids (PUFA) constitute an important group of molecules that promote health, while Saturated Fat Acids (SFA) intake represent a risk for atherosclerotic cardiovascular disease in humans. Substituting polyunsaturated fat for saturated fat reduces LDL cholesterol and the total cholesterol to high-density lipoprotein cholesterol ratio. Epidemiologic studies and randomized clinical trials have provided evidence that replacing saturated fat with polyunsaturated fat is beneficial for coronary heart disease.

Generally, for food analyses, total fatty acids must be extracts from sample and subsequently analyzed directly by weighing. The most important procedures and instruments involved in fatty acid profile determinations in food after derivatization procedures are reported in Table 7 .

Many studies were conducted about lipid profiles in food analyses, however, on fatty acids in gluten free foods, literature reported only few studies [7,19]. Alvarez [19] found that lipid content in amaranth and quinoa is between 2 and 3 times higher than in buckwheat and common cereals such as wheat (Table 2). Amaranth, quinoa and buckwheat lipids contain fatty acids having high degree of unsaturation, which is favorable from a nutritional point of view. Linoleic acid is the most abundant fatty acid (50\% of the total fatty acids in amaranth and quinoa, and approximately $35 \%$ in buckwheat) followed by oleic acid (25\% in amaranth and quinoa and 35\% in buckwheat) and palmitic acid [10,19,59-61]. High a-linolenic acid (C18:3 n-3) percentage is contained in quinoa seeds ranging from $3.8-8.3 \%$

Table 6. Microelement contents in gluten free food [33]

\begin{tabular}{|c|c|c|c|c|c|c|c|c|c|c|c|c|c|c|c|c|c|c|}
\hline \multirow{2}{*}{ Sample } & $\mathbf{V}$ & $\mathrm{Cr}$ & Mn & Co & $\mathbf{N i}$ & $\mathrm{Cu}$ & $\mathrm{Zn}$ & As & Se & $\mathrm{Sr}$ & Mo & Cd & Sn & Sb & $\mathbf{B a}$ & $\mathrm{Hg}$ & $\mathbf{P b}$ & $\mathbf{F e}$ \\
\hline & $\mathbf{u g} / \mathrm{g}$ & ug/g & $\mathrm{ug} / \mathrm{g}$ & $\mathbf{u g} / \mathrm{g}$ & $\mathrm{ug} / \mathrm{g}$ & ug/g & ug/g & ug/g & ug/g & ug/g & $\mathrm{ug} / \mathrm{g}$ & $\mathbf{u g} / \mathrm{g}$ & $\mathbf{u g} / \mathrm{g}$ & $\mathbf{u g} / \mathrm{g}$ & ug/g & $\mathbf{u g} / \mathrm{g}$ & $\mathbf{u g} / \mathrm{g}$ & ug/g \\
\hline Pasta & 0.0001 & 0.0091 & 0.47 & 0.0003 & 0.016 & 0.3 & 1.2 & 0.0004 & 0.010 & 0.016 & 0.074 & 0.0019 & 0.0071 & 0.0018 & 0.04 & 0.0010 & 0.33 & 1.1 \\
\hline Noodles & 0.0008 & 0.0268 & 1.6 & 0.0026 & 0.049 & 0.6 & 4.4 & 0.013 & 0.026 & 0.36 & 0.134 & 0.0043 & 0.0085 & 0.0044 & 0.38 & 0.0008 & 0.0061 & 4.6 \\
\hline Biscuits & 0.0044 & 0.015 & 3.9 & 0.0086 & 0.22 & 0.94 & 4.6 & 0.0064 & 0.016 & 0.18 & 0.108 & 0.010 & 0.0039 & 0.0045 & 0.17 & 0.0004 & 0.0051 & 4.6 \\
\hline Pasta fusilli & 0.0039 & 0.011 & 1.4 & 0.0008 & 0.25 & 0.49 & 3.8 & 0.0004 & 0.017 & 0.11 & 0.033 & 0.0019 & 0.0026 & 0.0025 & 0.09 & 0.0001 & 0.0033 & 6.2 \\
\hline Pasta Linguine & 0.0075 & 0.078 & 1.4 & 0.0570 & 0.53 & 0.49 & 3.8 & 0.0004 & 0.014 & 0.11 & 0.035 & 0.0018 & 0.0009 & 0.027 & 0.08 & 0.0001 & 0.0035 & 9.5 \\
\hline Egg noodles & 0.0021 & 0.031 & 1.9 & 0.0025 & 0.06 & 0.46 & 4.0 & 0.011 & 0.058 & 0.77 & 0.093 & 0.0084 & 0.0034 & 0.0026 & 0.26 & 0.0001 & 0.0014 & 5.4 \\
\hline Finger biscuits & 0.0065 & 0.16 & 0.80 & 0.0028 & 0.10 & 0.4 & 5.6 & 0.017 & 0.065 & 1.13 & 0.20 & 0.0024 & 0.0026 & 0.0096 & 0.31 & 0.0024 & 0.04 & 8.9 \\
\hline Buckwheat biscuits & 0.0093 & 0.040 & 5.0 & 0.0178 & 0.33 & 1.6 & 6.5 & 0.019 & 0.015 & 0.23 & 0.26 & 0.0174 & 0.0026 & 0.0093 & 0.45 & 0.0030 & 0.03 & 8.3 \\
\hline Croutons & 0.028 & 0.21 & 7.5 & 0.0270 & 0.50 & 0.63 & 3.6 & 0.022 & 0.037 & 4.7 & 0.37 & 0.0079 & 0.0028 & 0.019 & 0.76 & 0.0031 & 0.04 & 13.7 \\
\hline Rice noodles & 0.0033 & 0.13 & 5.1 & 0.0151 & 0.14 & 1.7 & 10.7 & 0.088 & 0.027 & 0.44 & 0.47 & 0.026 & 0.0028 & 0.0083 & 1.00 & 0.0049 & 0.03 & 3.6 \\
\hline Couscous & 0.0029 & 0.040 & 1.0 & 0.0101 & 0.31 & 0.48 & 3.2 & 0.0081 & 0.023 & 0.16 & 0.20 & 0.0044 & 0.0026 & 0.0053 & 0.15 & 0.0015 & 0.02 & 4.3 \\
\hline Corn couscous & 0.0054 & 0.063 & 0.81 & 0.024 & 0.12 & 0.37 & 2.9 & 0.0078 & 0.0088 & 0.16 & 0.11 & 0.0028 & 0.0026 & 0.010 & 0.14 & 0.0010 & 0.02 & 5.0 \\
\hline Lasagna & 0.071 & 14.4 & 2.5 & 0.54 & 15.0 & 1.5 & 7.2 & 0.017 & 0.062 & 1.8 & 0.41 & 0.021 & 0.0030 & 0.026 & 0.88 & 0.0325 & 0.21 & 99 \\
\hline Corn flakes & 0.028 & 8.4 & 2.1 & 0.15 & 10.3 & 1.1 & 3.3 & 0.0086 & 0.062 & 0.70 & 0.30 & 0.040 & 0.0084 & 0.0066 & 0.91 & 0.0183 & 0.34 & 55 \\
\hline Dietetic biscuits & 0.049 & 9.1 & 1.5 & 0.15 & 10.0 & 1.2 & 3. & 0.014 & 0.016 & 1.4 & 0.24 & 0.013 & 0.0031 & 0.014 & 0.61 & 0.065 & 0.19 & 62 \\
\hline Breadsticks & 0.035 & 8.7 & 4.4 & 0.16 & 10.5 & 1.1 & 5.0 & 0.036 & 0.026 & 0.75 & 0.28 & 0.020 & 0.0030 & 0.013 & 0.44 & 0.082 & 0.10 & 62 \\
\hline Local bread B. & 0.074 & 8.7 & 3.1 & 0.17 & 10.3 & 1.7 & 5.8 & 0.014 & 0.019 & 5.1 & 0.24 & 0.023 & 0.0031 & 0.017 & 2.8 & 0.037 & 0.26 & 66 \\
\hline Local bread P. & 0.036 & 8.7 & 4.8 & 0.16 & 10.2 & 1.8 & 8.4 & 0.056 & 0.013 & 2.2 & 0.33 & 0.032 & 0.0046 & 0.016 & 0.63 & 0.13 & 0.39 & 70 \\
\hline Corn flakes & 0.031 & 8.1 & 2.1 & 0.15 & 10.0 & 1.1 & 3.5 & 0.0086 & 0.065 & 0.56 & 0.29 & 0.024 & 0.0035 & 0.0049 & 0.88 & 0.013 & 0.20 & 60 \\
\hline Shortbread & 0.033 & 9.7 & 3.8 & 0.19 & 12.4 & 1.4 & 137 & 0.044 & 0.033 & 0.51 & 0.36 & 0.12 & 0.0031 & 0.0096 & 0.62 & 0.015 & 1.09 & 80 \\
\hline Biscuits & 0.057 & 14.0 & 4.7 & 0.20 & 14.0 & 1.6 & 7.4 & 0.032 & 0.051 & 0.94 & 0.35 & 0.016 & 0.0028 & 0.028 & 0.46 & 0.022 & 0.074 & 83 \\
\hline Butter cookies & 0.054 & 14.0 & 4.6 & 0.19 & 13.8 & 1.1 & 6.0 & 0.043 & 0.009 & 0.32 & 0.42 & 0.024 & 0.0028 & 0.016 & 0.58 & 0.021 & 0.063 & 75 \\
\hline Croutons & 0.005 & 0.031 & 4.4 & 0.013 & 0.11 & 1.8 & 6.7 & 0.062 & 0.021 & 1.5 & 0.36 & 0.014 & 0.0026 & 0.0011 & 0.38 & 0.017 & 0.026 & 10 \\
\hline Egg biscuits & 0.014 & 0.035 & 6.1 & 0.011 & 0.21 & 1.3 & 6.3 & 0.055 & 0.016 & 1.6 & 0.32 & 0.021 & 0.0026 & 0.0013 & 0.32 & 0.0095 & 0.028 & 4.6 \\
\hline Industrial bread & 0.052 & 0.054 & 2.2 & 0.015 & 0.17 & 0.94 & 3.7 & 0.020 & 0.014 & 1.5 & 0.28 & 0.0050 & 0.0026 & 0.0031 & 0.60 & 0.0059 & 0.052 & 21 \\
\hline
\end{tabular}


[61]. A high percentage of $\alpha$-linolenic acid is advantageous because reduces cardiovascular disease, cancer, osteoporosis, inflammatory and autoimmune diseases [62].

Several authors $[23,51]$ affirm that the lipid content of teff $(3.7-4.4$ $\%)$ is higher than that of wheat (3.6\%), rice $(0.9 \%)$, sorghum $(3.5 \%)$, and maize $(2.5 \%)$ flours, and was lower than that of oat $(6.7 \%)$ and quinoa $(8.6 \%)[23,63]$. The majority of the free fatty acids are unsaturated $(84 \%)$ and are similar to that of maize, sorghum, and quinoa. Linoleic (50\%) and oleic (29\%) are the predominant acids and are similar to those of sorghum and maize [63]. Other analyses carried out by Gebremariam [24] showed that the content of oleic acid (32\%) was higher than that of linoleic acid (24\%) as affirmed previously. As in other cases, the variances may be due to the different analytical methods and teff genetics (Table 8).

A recent study [7] carried out by us included 35 different products (snacks, biscuits, bakery products, pasta, flours, etc.) from several Italian manufacturers. Table 9 shows the data concerning proteins, energy, carbohydrates, and salts of the foods taken into consideration for the determination of individual fatty acids. The data in Table 9, with the exception of the total and saturated fatty acids content, were obtained from the labels of the aforementioned gluten free products. Furthermore, Table 9 shows, for comparison $\left(\mathrm{R}_{\text {flour } 0,} \mathrm{R}_{\text {flour } 00,}\right.$ etc.), the data concerning some containing gluten. After extraction and esterification, the fatty acid composition was determined by gas chromatography (Table 10). The mean content of total lipids was $12.6 \%$. The highest percentages were found in a wafer biscuit $(25 \%)$ and in a muffin $(23 \%)$ sample, while the lowest in a flour mix for bread (1.2\%). Saturated fatty acids were contained in all analyzed samples ranging from 2.8 to $72 \%$. The highest contents were found in the wafer biscuit (72\%) in an Easter cake $(66 \%)$ and in the rice, corn, and red fruit flakes sample (63\%), while the lowest $(2.8 \%)$ percentage in a biscuit sample. Palmitic acid was the major component, and high amounts of this fatty acid were detected in all samples. Meanly, monounsaturated fatty acids (MUFAs) were found to be the major constituents (57\%), followed by saturated fatty acids (SFAs) (30\%), and polyunsaturated fatty acid (13\%). Only 15 of the 35 gluten-free products analyzed supply adequate energy intake, while, in 11 samples, saturated fatty acids were found to give more energy than that recommended by the European Food Safety Authority EFSA [64]. Moreover, data analyses showed that, although gluten-free commercial products are high added-value foods, industrial products in many cases contain palm and palm kernel oils, whereas the local producers generally use the finest raw materials, such as olive oil.

Albuquerque [65] studying nuts and oilseeds, often used in the preparation of gluten free cakes, showed the highest fat content of these ingredients followed by sauces, potato and potato-products, and snacks samples. These were also the ingredient showed a higher MUFA and PUFA contents, whose percentages were significantly higher in the nuts and oilseeds.

\section{Proteins}

According to information furnished by suppliers, an evaluation on the nutritional characteristics of gluten-free breads representative of the Spanish market was carried out by Matos Segura [32]. The authors established that the protein, fat and mineral content of the gluten-free breads showed great variation, ranging from 9.0 to $155 \mathrm{~g} \mathrm{Kg}^{-1} \mathrm{~g}, 20.0$ to $261 \mathrm{~g} \mathrm{Kg}^{-1}$ and 11.0 to $54.3 \mathrm{Kg}^{-1}$, respectively. Furthermore, glutenfree breads show very low contribution to the recommended daily protein intake, with a high contribution to the carbohydrate dietary reference intake. A research affirms that the protein contents of two variety of teff are 12.8 and $10.5 \%$, which result higher compared to that of other cereals $[63,66]$.

Table 7. Procedures and instruments used in fatty acid determination in food sample

\begin{tabular}{|c|c|c|c|}
\hline Sample & Extraction/purification procedure & Derivatization procedures & Analytical instrument \\
\hline Oil & $\begin{array}{c}\text { SPE; Dilution } \\
\text { SPE; Dilution } \\
\text { Bligh and Dyer method }\end{array}$ & $\begin{array}{c}\mathrm{KOH} \text { in methanol } \\
\mathrm{CH}_{3} \mathrm{NaO} \text { in methanol } \\
\mathrm{BHT} \text { in methanol }\end{array}$ & $\begin{array}{l}\text { GC-FID; GC-MS; } \\
\text { GC-FID; GC-MS; } \\
\text { GC-FID; GC-MS; } \\
\text { HPLC-MS; } \\
\text { HPLC-MS; }\end{array}$ \\
\hline $\begin{array}{l}\text { Liquid sample } \\
\text { (milk, fruit juice) }\end{array}$ & Funnel separation & $\begin{array}{c}\mathrm{KOH} \text { in methanol } \\
\mathrm{CH}_{3} \mathrm{NaO} \text { in methanol } \\
\mathrm{BHT} \text { in methanol }\end{array}$ & $\begin{array}{l}\text { GC-FID; GC-MS; } \\
\text { GC-FID; GC-MS; } \\
\text { GC-FID; GC-MS; } \\
\text { HPLC-MS; } \\
\text { HPLC-MS; }\end{array}$ \\
\hline Solid samples & $\begin{array}{c}\text { Soxhlet } \\
\text { Ultrasonic bath }\end{array}$ & $\begin{array}{c}\mathrm{KOH} \text { in methanol } \\
\mathrm{CH}_{3} \mathrm{NaO} \text { in methanol }\end{array}$ & GC-FID; GC-MS; \\
\hline
\end{tabular}

Table 8. Micro and macro nutrient contents in several gluten free food

\begin{tabular}{|c|c|c|c|c|c|c|c|c|c|c|c|c|c|c|c|c|}
\hline \multirow{2}{*}{ Ref. } & \multirow{2}{*}{ Sample } & Minerals & $\mathbf{N a}$ & Mn & $\mathrm{Fe}$ & $\mathrm{Cu}$ & $\mathbf{Z n}$ & $\mathrm{Cr}$ & Co & As & $\mathrm{Se}$ & Cd & $\mathbf{P b}$ & Fatty acid & Protein & Sugar \\
\hline & & ug/g & ug/g & $\mathbf{u g} / \mathrm{g}$ & $\mathbf{u g} / \mathrm{g}$ & $\mathbf{u g} / \mathrm{g}$ & $\mathbf{u g} / \mathrm{g}$ & $\mathbf{u g} / \mathrm{g}$ & $\mathbf{u g} / \mathrm{g}$ & $\mathbf{u g} / \mathrm{g}$ & $\mathrm{ug} / \mathrm{g}$ & ug/g & ug/g & ug/g & $\mathrm{mg} / \mathrm{g}$ & $\mathbf{m g} / \mathrm{g}$ \\
\hline$[18]$ & G. F. products from Vicia faba & - & - & - & - & - & - & - & - & - & - & - & - & 18000 & 300000 & - \\
\hline$[2]$ & Bakery Products & 760 & - & - & - & - & - & - & - & - & - & - & - & 174600 & - & - \\
\hline$[2]$ & Cookies. biscuit and wafers & 700 & - & - & - & - & - & - & - & - & - & - & - & 201600 & - & - \\
\hline$[23]$ & Cookies. cereal bars & - & - & 9 & 13.5 & 2.1 & 8.4 & 43 & 13 & 53 & 101 & 11 & 69 & - & - & - \\
\hline$[13]$ & Cereal bars & - & 54 & - & - & - & - & - & - & - & - & - & - & 50000 & 90 & 300 \\
\hline$[13]$ & Cake & - & 300 & - & - & - & - & - & - & - & - & - & - & 340000 & 50 & 440 \\
\hline [13] & Sweet biscuits & - & 183 & - & - & - & - & - & - & - & - & - & - & 130000 & 45 & 310 \\
\hline$[13]$ & Ice Cream & - & 490 & - & - & - & - & - & - & - & - & - & - & 51000 & 33 & 184 \\
\hline$[13]$ & Corn and potato chips & - & 5960 & - & - & - & & - & - & - & - & - & - & 40000 & 60 & 30 \\
\hline$[13]$ & Cured meats. sausages and hot dogs & - & 10560 & - & - & - & - & - & - & - & - & - & - & 80000 & 180 & 90 \\
\hline$[13]$ & Sugar-based confectioneries & - & 5100 & - & - & - & - & - & - & - & - & - & - & 20000 & 3400 & 380 \\
\hline
\end{tabular}


Table 9. Nutritional characteristics of analyzed gluten free samples and reference food $\left(R_{x}\right)[7]$

\begin{tabular}{|c|c|c|c|c|c|c|c|}
\hline $\mathbf{N}^{\circ}$ & Sample & $\begin{array}{c}\text { Energy } \\
(\text { Kcal } / 100 \text { g) }\end{array}$ & $\begin{array}{l}\text { Total fats } \\
(\mathrm{g} / 100 \mathrm{~g})\end{array}$ & $\begin{array}{l}\text { Saturated fatty acids } \\
(\mathrm{g} / \mathbf{1 0 0} \mathrm{g})\end{array}$ & $\begin{array}{l}\text { Carbohydrates } \\
(\mathrm{g} / 100 \mathrm{~g})\end{array}$ & $\begin{array}{l}\text { Proteins } \\
(\mathrm{g} / 100 \mathrm{~g})\end{array}$ & Sals $(g / 100 g)$ \\
\hline \multicolumn{8}{|c|}{ Flours } \\
\hline 1 & Rice flour & 365 & 1.3 & 0.29 & 80.15 & 6.67 & 0.1 \\
\hline 2 & Red teff flour & 380 & 1.4 & 0.27 & - & - & - \\
\hline 3 & Flour for bread & 352 & 1.2 & 0.3 & 79.6 & 5 & 0.01 \\
\hline Rflour0 & Flour 0 with gluten & 363 & 1.5 & 0.27 & 73.8 & 11.5 & - \\
\hline Rfflour00 & Flour 00 with gluten & 366 & 1.5 & 0.3 & 76.2 & 9.7 & - \\
\hline Rfrice & Rice flour & 366 & 1.4 & 0.39 & 80.1 & 5.9 & - \\
\hline Rfcorn & Corn flour & 375 & 1.4 & 0.17 & 82.8 & 5.6 & - \\
\hline \multicolumn{8}{|c|}{ Bread } \\
\hline 4 & Handcrafted bread & 360 & 3.7 & 0.9 & - & - & - \\
\hline Rbread1 & Bread with gluten & 271 & 3.5 & 0.86 & 50 & 8.8 & - \\
\hline Rbread2 & White Bread with gluten & 238 & 2.1 & 0.63 & 43.9 & 10.6 & - \\
\hline \multicolumn{8}{|c|}{ Breadsticks } \\
\hline 5 & Breadsticks a & 425 & 9 & 1.8 & 75 & 2.4 & 1.9 \\
\hline 6 & Breadsticks b & 416 & 8.5 & 3.2 & 79.9 & 4 & 2.7 \\
\hline 7 & Breadsticks c & 462 & 17.2 & 2.54 & 73.57 & 0.99 & 1.6 \\
\hline 8 & Breadsticks d & 446 & 14.6 & 2.9 & 75 & 2.4 & 1.9 \\
\hline 9 & Breadsticks with olive oil & 431 & 12 & 3.5 & 79 & 1.3 & 2.12 \\
\hline 10 & Breadsticks with rosemary & 460 & 16 & 5.13 & 76.32 & 2.04 & 2.8 \\
\hline 11 & Mini breadsticks & 427 & 12.8 & 1.7 & 74.9 & 1.4 & 1.2 \\
\hline \multicolumn{8}{|c|}{ Crackers } \\
\hline 12 & Buckwheat crackers & 369 & 3.6 & 0.6 & 72 & 9.1 & 2 \\
\hline 13 & Crackers with rosemary & 446 & 12 & 7.1 & 79 & 3.3 & 1.3 \\
\hline 14 & Rice Crackers & 454 & 13.8 & 1.3 & 78.5 & 2.8 & 1.9 \\
\hline 15 & Turmeric crackers & 455 & 17 & 1.8 & 66 & 7.6 & 2.1 \\
\hline Rcrackers & Crackers with gluten & 421 & 8.9 & 2 & 74.3 & 9.5 & - \\
\hline 16 & Corn and quinoa crackers & 422 & 9.8 & 0.9 & 79.5 & 1.8 & 1.7 \\
\hline \multicolumn{8}{|c|}{ Snack } \\
\hline 17 & Apricot snack & 620 & 7.5 & 0.99 & 71 & 2.5 & 0.23 \\
\hline 18 & Crispy sheets & 436 & 12 & 1.5 & 78.5 & 2 & 1.86 \\
\hline 22 & Rice and corn flakes & 382 & 2 & 0.4 & 83 & 6.4 & 0.3 \\
\hline \multicolumn{8}{|c|}{ Biscuits } \\
\hline 19 & Chocolate biscuits & 453 & 14 & 7.7 & 77 & 4 & 0.55 \\
\hline 20 & Biscuits d & 422 & 18.4 & 2.3 & 66.3 & 4.6 & 0.3 \\
\hline 21 & Biscuits f & 451 & 15 & 7.8 & 72 & 5.4 & 0.4 \\
\hline 23 & Lemon biscuits & 435 & 11 & 1.5 & 78 & 4.6 & 0.9 \\
\hline 24 & Seven cereal biscuits & 456 & 16.5 & 9.1 & 72 & 3.5 & 3 \\
\hline 25 & Biscuits o & 456 & 13 & 4.6 & 83 & 2 & 0.57 \\
\hline 26 & Chocolate wafer & 505 & 25 & 16 & 62.1 & 6.4 & 0.25 \\
\hline $\mathrm{Rw}$ & Wafer with gluten & 433 & 14.2 & 4.2 & 72.4 & 6.6 & - \\
\hline 29 & Biscuits n & 439 & 14 & 4.2 & 69.4 & 7 & 0.7 \\
\hline 30 & Tumeric biscuits & 441 & 16 & 1.8 & 78 & 2.3 & 0.33 \\
\hline 31 & Chocolate biscuits & 425 & 11.7 & 2.7 & 73.6 & 5.1 & 0.8 \\
\hline 33 & Buckwheat biscuits & 444 & 14 & 8.9 & 72 & 4.2 & 0.85 \\
\hline 34 & Biscuits c & 372 & 19.9 & 2.5 & 52.8 & 4.4 & 0.07 \\
\hline 35 & Crunchy cereal biscuits & 472 & 18 & 8 & 70 & 5.3 & 0.75 \\
\hline \multicolumn{8}{|c|}{ Muffin and cakes } \\
\hline 27 & Easter cake & 410 & 18 & 14 & - & - & - \\
\hline 32 & Quinoa cake & 407 & 17 & 2.5 & 55 & 7.3 & 0.5 \\
\hline 28 & Chocolate muffin & 441 & 23 & 8.6 & 52 & 3.9 & 0.5 \\
\hline $\mathrm{Rm}$ & English muffin with gluten & 223 & 2 & 0.29 & 44.8 & 8.7 & - \\
\hline
\end{tabular}


Table 10. Fatty acids composition (\% on total fats) of gluten free food (the numbering and the description of the samples correspond to those of table 8) [7]

\begin{tabular}{|c|c|c|c|c|c|c|c|c|c|c|c|c|c|c|c|c|c|c|c|c|c|c|c|c|c|c|c|c|c|c|c|c|c|c|c|c|}
\hline \multirow{2}{*}{ Fatty acid } & \multicolumn{36}{|c|}{ Samples } \\
\hline & 1 & 2 & 3 & 4 & 5 & 6 & 7 & 8 & 9 & 10 & 11 & 12 & 13 & 14 & 15 & 16 & 17 & 18 & 19 & 20 & 21 & 22 & 23 & 24 & 25 & 26 & 27 & 28 & 29 & 30 & 31 & 32 & 33 & 34 & 35 & nean \\
\hline 4:0 & 0,01 & 0,01 & 0,01 & 0,01 & 0,01 & 0,01 & 0,01 & 0,01 & 0,01 & 0,01 & $0,01 \mathrm{C}$ & 0,01 & \begin{tabular}{|l|l|}
0,01 & 0 \\
\end{tabular} & \begin{tabular}{l|l}
0,01 & 0 \\
\end{tabular} & \begin{tabular}{l|l}
0,01 & 0 \\
\end{tabular} & \begin{tabular}{l|l}
0,01 & 0 \\
\end{tabular} & \begin{tabular}{l|l}
0,01 & 0 \\
\end{tabular} & \begin{tabular}{l|l}
0,01 & 0 \\
\end{tabular} & \begin{tabular}{l|l}
0,22 & 0,
\end{tabular} & 0,01 & 0,010 & 0,010 & \begin{tabular}{|l|l|}
0,01 & 1 \\
\end{tabular} & \begin{tabular}{|l|l|}
1,29 & 0
\end{tabular} & \begin{tabular}{l|l}
0,21 & 0 \\
\end{tabular} & \begin{tabular}{l|l}
0,01 & 0 \\
\end{tabular} & \begin{tabular}{|l|l}
0,08 & 0 \\
\end{tabular} & \begin{tabular}{l|l}
0,01 & 0 \\
\end{tabular} & \begin{tabular}{c|c}
0,01 & 0 \\
\end{tabular} & 0,01 & 0,01 & 0,01 & \begin{tabular}{|l|l|}
0,4 & 0 \\
\end{tabular} & 0,01 & 0,01 & 71 \\
\hline $6: 0$ & & 0,01 & 0,01 & 0,01 & 0,01 & 0,01 & 0,01 & 3 & 0,01 & 0,01 & $0,01 \mathrm{C}$ & \begin{tabular}{|l|l}
0,01 & 0
\end{tabular} & \begin{tabular}{|l|l}
0,01 & 0
\end{tabular} & \begin{tabular}{l|l}
0,01 & 0
\end{tabular} & \begin{tabular}{l|l}
0,01 & 0 \\
\end{tabular} & \begin{tabular}{l|l}
0,01 & 0 \\
\end{tabular} & \begin{tabular}{l|l}
0,01 & 0 \\
\end{tabular} & \begin{tabular}{l|l}
0,01 & 0
\end{tabular} & \begin{tabular}{l|l}
0,54 & 0,
\end{tabular} & 0,01 & 0,06 & 0,3 & 0,012 & \begin{tabular}{l|l|}
2,25 & 0
\end{tabular} & 0,24 & 01 & \begin{tabular}{l|l}
1,3 & 0 \\
\end{tabular} & \begin{tabular}{l|l}
0,01 & 0
\end{tabular} & \begin{tabular}{c|c}
0,01 & 0
\end{tabular} & 0,01 & 0,01 & 0,01 & \begin{tabular}{|l|l|}
0,6 & 0 \\
\end{tabular} & 0,01 & 0,01 & 162 \\
\hline C8:0 & 01 & 0,01 & 0,01 & 0,01 & 0,01 & 0,04 & 0,01 & 0,04 & 0,01 & 0,01 & $0,01 \mathrm{C}$ & 0,01 & \begin{tabular}{|l|l|}
0,01 & 0 \\
\end{tabular} & \begin{tabular}{l|l}
0,01 & 0 \\
\end{tabular} & \begin{tabular}{l|l}
0,01 & 0 \\
\end{tabular} & \begin{tabular}{l|l}
0,01 & 0 \\
\end{tabular} & \begin{tabular}{l|l}
0,01 & 0 \\
\end{tabular} & \begin{tabular}{l|l}
0,01 & 0 \\
\end{tabular} & \begin{tabular}{l|l}
0,42 & 0,
\end{tabular} & 0,01 & \begin{tabular}{|l|l|}
0,8 & 1 \\
\end{tabular} & 1,840 & 0,013 & 3,060 & 0,23 & \begin{tabular}{l|l|}
1,7 & 0 \\
\end{tabular} & \begin{tabular}{l|l}
0,87 & 0 \\
\end{tabular} & \begin{tabular}{l|l}
0,01 & 0 \\
\end{tabular} & \begin{tabular}{l|l}
0,01 & 0 \\
\end{tabular} & 0,01 & 0,01 & 0,01 & \begin{tabular}{|l|l|}
0,94 & 0 \\
\end{tabular} & 010 & 0,01 & 291 \\
\hline 10:0 & 1 & 0,01 & 0,01 & 0,01 & 0,01 & 0,05 & 0,01 & 0,03 & 0,01 & 0,01 & 0,05 & 0,01 & \begin{tabular}{|l|l|}
0,02 & 0 \\
\end{tabular} & \begin{tabular}{l|l}
0,01 & 0
\end{tabular} & \begin{tabular}{l|l}
0,01 & 0
\end{tabular} & \begin{tabular}{l|l}
0,01 & 0 \\
\end{tabular} & \begin{tabular}{l|l}
0,01 & 0
\end{tabular} & \begin{tabular}{l|l}
0,01 & 0
\end{tabular} & \begin{tabular}{l|l}
0,63 & 0,
\end{tabular} & 0,01 & \begin{tabular}{|l|l}
0,82 & 1
\end{tabular} & 1,650 & $0,01 \quad 0$ & \begin{tabular}{|l|l}
0,65 & 0
\end{tabular} & \begin{tabular}{l|l}
0,67 & 2 \\
\end{tabular} & 2,32 & \begin{tabular}{l|l}
1,5 & 0 \\
\end{tabular} & \begin{tabular}{l|l}
0,03 & 0 \\
\end{tabular} & \begin{tabular}{c|c}
0,01 & 0 \\
\end{tabular} & 0,04 & 0,01 & 0,01 & \begin{tabular}{|l|l|}
2,5 & 0 \\
\end{tabular} & 0,01 & 0,01 & 321 \\
\hline $11: 0$ & 1 & 0,01 & 0,01 & 0,01 & 0,01 & 0,01 & 0,01 & 0,01 & 0,01 & 0,01 & 0,01 & \begin{tabular}{|l|l|}
0,01 & 0
\end{tabular} & \begin{tabular}{|l|l}
0,01 & 0
\end{tabular} & \begin{tabular}{l|l}
0,01 & 0
\end{tabular} & \begin{tabular}{l|l}
0,01 & 0 \\
\end{tabular} & \begin{tabular}{l|l}
0,01 & 0 \\
\end{tabular} & \begin{tabular}{l|l}
0,01 & 0 \\
\end{tabular} & \begin{tabular}{l|l}
0,01 & 0
\end{tabular} & \begin{tabular}{l|l}
0,06 & 0,
\end{tabular} & 0,01 & 0,040 & 0,010 & 0,010 & 0,140 & \begin{tabular}{l|l}
0,01 & 0 \\
\end{tabular} & \begin{tabular}{l|l}
0,02 & 0
\end{tabular} & \begin{tabular}{l|l}
0,03 & 0 \\
\end{tabular} & \begin{tabular}{l|l}
0,01 & 0 \\
\end{tabular} & \begin{tabular}{l|l}
0,01 & 0 \\
\end{tabular} & 0,01 & 0,01 & 0,01 & \begin{tabular}{|l|l|}
0,01 & 0 \\
\end{tabular} & \begin{tabular}{|l|l}
0,01 & 0
\end{tabular} & 0,01 & 017 \\
\hline 12:0 & 1 & 0,01 & 0,01 & 0,01 & 0,16 & 0,39 & 0,01 & 0,08 & 0,01 & 0,01 & 0,2 & 0,01 & \begin{tabular}{|l|l|}
0,21 & 0 \\
\end{tabular} & \begin{tabular}{l|l}
0,01 & 0 \\
\end{tabular} & \begin{tabular}{l|l}
0,01 & 0 \\
\end{tabular} & \begin{tabular}{l|l}
0,02 & 0 \\
\end{tabular} & \begin{tabular}{l|l}
0,01 & 0 \\
\end{tabular} & \begin{tabular}{l|l}
0,01 & 0 \\
\end{tabular} & \begin{tabular}{l|l}
0,88 & 0,
\end{tabular} & 0,01 & 10,1 & 16,90 & \begin{tabular}{|l|l|}
0,01 & 1 \\
\end{tabular} & $\begin{array}{lll}1,89 & 0\end{array}$ & \begin{tabular}{l|l}
0,96 & 2 \\
\end{tabular} & 20,6 & \begin{tabular}{l|l}
2,8 & 0 \\
\end{tabular} & \begin{tabular}{l|l}
0,67 & 0 \\
\end{tabular} & \begin{tabular}{l|l}
0,01 & 0
\end{tabular} & 0,01 & 0,01 & 0,01 & \begin{tabular}{|l|l|l|}
3,5 & 0
\end{tabular} & 0,01 & 0,04 & 70 \\
\hline 13:0 & & 0,01 & 0,01 & 0,01 & 0,01 & 0,01 & 0,01 & 0,01 & 0,01 & 0,01 & 0,01 & \begin{tabular}{|l|l|l|}
0,01 \\
0
\end{tabular} & \begin{tabular}{|l|l|l|}
0,01 & 0
\end{tabular} & \begin{tabular}{l|l}
0,01 & 0
\end{tabular} & \begin{tabular}{l|l}
0,01 & 0
\end{tabular} & \begin{tabular}{l|l}
0,01 & 0
\end{tabular} & \begin{tabular}{l|l}
0,01 & 0
\end{tabular} & \begin{tabular}{l|l}
0,01 & 0
\end{tabular} & \begin{tabular}{l|l}
0,1 & 0,
\end{tabular} & 0,01 & 0,010 & 0,010 & 0,010 & 0,450 & \begin{tabular}{l|l|l}
0,04 & 0
\end{tabular} & \begin{tabular}{|l|l|}
0,04 & 0
\end{tabular} & \begin{tabular}{l|l}
0,09 & 0
\end{tabular} & \begin{tabular}{l|l}
0,01 & 0
\end{tabular} & \begin{tabular}{l|l}
0,01 & 0
\end{tabular} & 0,01 & 0,01 & 0,01 & \begin{tabular}{|l|l|l|}
0,11 & 0
\end{tabular} & 10 & 0,01 & 03 \\
\hline C14:1 & 1 & 0,01 & 0,01 & 0,01 & 0,01 & 0,01 & 0,01 & 0,01 & 0,01 & 0,01 & 0,01 & 0,01 & 0,010 & \begin{tabular}{l|l}
0,01 & 0
\end{tabular} & \begin{tabular}{l|l}
0,01 & 0
\end{tabular} & \begin{tabular}{l|l}
0,01 & 0
\end{tabular} & \begin{tabular}{l|l}
0,01 & 0
\end{tabular} & \begin{tabular}{l|l}
0,01 & 0
\end{tabular} & \begin{tabular}{l|l}
0,22 & 0,
\end{tabular} & 0,010 & 0,01 & 0,010 & 0,01 & \begin{tabular}{|l|l}
4,0 & 0
\end{tabular} & \begin{tabular}{l|l|l}
0,49 & 0
\end{tabular} & $\begin{array}{ll}0,01 & 0\end{array}$ & \begin{tabular}{l|l}
0,620 \\
\end{tabular} & \begin{tabular}{l|l}
0,01 & 0
\end{tabular} & \begin{tabular}{c|c}
0,01 & 0
\end{tabular} & 0,010 & 0,01 & 0,06 & , 1 & 010 & 01 & 20 \\
\hline C14:0 & 8 & 0,01 & 17,7 & 1,2 & 0,01 & 1,3 & 0,01 & 0,32 & 0,1 & 0,01 & 0,79 & 0,05 & \begin{tabular}{|l|}
1,3 \\
\end{tabular} & \begin{tabular}{l|l}
0,0 & 0
\end{tabular} & \begin{tabular}{|l|l}
0,03 & 0
\end{tabular} & \begin{tabular}{l|l}
0,05 & 0
\end{tabular} & \begin{tabular}{l|l}
0,09 & 0
\end{tabular} & \begin{tabular}{l|l}
0,17 & 3
\end{tabular} & \begin{tabular}{l|l}
3,3 & 0 \\
\end{tabular} & 0,2 & \begin{tabular}{|l|l}
4,6 & 1
\end{tabular} & 10,60 & \begin{tabular}{|l|l}
0,05 & 8
\end{tabular} & \begin{tabular}{|l|l}
8,11 & 3 \\
\end{tabular} & \begin{tabular}{l|l}
3,15 & 1 \\
\end{tabular} & 12,6 & \begin{tabular}{l|l|l}
9,3 & 0 \\
\end{tabular} & \begin{tabular}{|l|l}
0,26 & 0
\end{tabular} & \begin{tabular}{l|l}
0,01 & 0
\end{tabular} & 0,160 & 0,06 & 0,12 & 11,00 & 0,04 & 0,64 & 50 \\
\hline $15: 1$ & & 1 & 0,01 & 0,01 & 0,01 & 0,01 & 0,01 & 0,01 & 0,01 & 0,01 & 0,01 & 0,01 & 0,010 & \begin{tabular}{l|l}
0,01 & 0
\end{tabular} & \begin{tabular}{l|l}
0,01 & 0
\end{tabular} & \begin{tabular}{l|l}
0,01 & 0
\end{tabular} & \begin{tabular}{|l|l}
0,01 & 0
\end{tabular} & \begin{tabular}{l|l}
0,01 & 0
\end{tabular} & \begin{tabular}{l|l}
0,01 & 0,
\end{tabular} & 0,010 & 0,01 & 0,01 & \begin{tabular}{|l|l|l|}
0,01 & 0
\end{tabular} & \begin{tabular}{|l|l|l}
0,01 & 0
\end{tabular} & \begin{tabular}{l|l}
0,01 & 0
\end{tabular} & 0,010 & \begin{tabular}{|l|l}
0,01 & 0
\end{tabular} & \begin{tabular}{l|l}
0,01 & 0
\end{tabular} & \begin{tabular}{l|l}
0,01 & 0
\end{tabular} & 0,010 & 0,01 & 0,01 & \begin{tabular}{l|l}
01 & 0 \\
\end{tabular} & 10 & 0 & \\
\hline C15:0 & 0,01 & 0,01 & 0,01 & 0,01 & 0,01 & 0,1 & 0,01 & 0,01 & 0,01 & 0,01 & 0,05 & \begin{tabular}{|l|l|}
0,03 \\
\end{tabular} & 0,110 & \begin{tabular}{|l|l}
0,01 & 0 \\
\end{tabular} & 0,01 & \begin{tabular}{l|l}
0,0 & 0
\end{tabular} & \begin{tabular}{l|l}
0,01 & 0
\end{tabular} & \begin{tabular}{l|l}
0,02 & 0
\end{tabular} & \begin{tabular}{l|l}
0,64 & 0,
\end{tabular} & 0,050 & 0,17 & 0,010 & \begin{tabular}{|l|c|}
0,01 \\
\end{tabular} & \begin{tabular}{|l|l|}
0,7 & 0 \\
\end{tabular} & \begin{tabular}{l|l}
0,6 & 0
\end{tabular} & \begin{tabular}{l|l}
0,08 & 0
\end{tabular} & \begin{tabular}{|l|l|l}
0,76 & 0
\end{tabular} & \begin{tabular}{|l|l}
0,16 & 0
\end{tabular} & \begin{tabular}{l|l}
0,01 & 0
\end{tabular} & 0,020 & 0,01 & 0,03 & 1,440 & 0,01 & 0,03 & 15 \\
\hline $16: 1$ & 1 & 0,01 & 0,01 & 0,01 & 1,3 & 0,6 & 0,01 & 7,4 & 1,23 & 0,01 & 1,1 & 1,7 & \begin{tabular}{|l|l|}
0,53 & 0
\end{tabular} & \begin{tabular}{l|l}
0,01 & 0
\end{tabular} & 0,01 & \begin{tabular}{l|l}
0,0 & 0
\end{tabular} & \begin{tabular}{c|c}
0,11 & 0
\end{tabular} & \begin{tabular}{l|l}
0,58 & 1
\end{tabular} & \begin{tabular}{l|l}
1,16 & 0,
\end{tabular} & 0,01 & 1,2 & 0,010 & \begin{tabular}{|l|l}
0,29 & 1
\end{tabular} & \begin{tabular}{|l|l|}
1,03 & 1
\end{tabular} & \begin{tabular}{l|l|l|l}
1,02 & 0
\end{tabular} & \begin{tabular}{l|l}
0,26 & 0
\end{tabular} & \begin{tabular}{l|l}
0,98 & 2
\end{tabular} & \begin{tabular}{l|l|l}
2,87 & 0
\end{tabular} & 0,01 & \begin{tabular}{l|l}
0,5 & 0
\end{tabular} & 0,43 & 0,71 & 1,770 & 0,380 & 0,01 & 77 \\
\hline $16 \cdot 0$ & & 13,6 & 0 , & & 11,5 & 33,3 & 4,5 & 22,8 & 11,9 & 34,3 & & 18,65 & 51,1 & 2,8 & 40 & 2,2 & \begin{tabular}{l|l}
9,7 & 1
\end{tabular} & & & & & & & & & & & & & 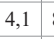 & \begin{tabular}{l|l}
9 & 1
\end{tabular} & & & \begin{tabular}{l|l}
8 & 4
\end{tabular} & & \\
\hline C17:1 & 0,01 & 0,01 & 0,01 & 0,01 & 0,23 & 0,14 & 0,01 & 0,74 & 0,13 & 0,01 & 0,2 & \begin{tabular}{|l|}
0,01 \\
\end{tabular} & \begin{tabular}{|l|l|l|}
0,2 & 0 \\
\end{tabular} & \begin{tabular}{l|l}
0,01 & 0 \\
\end{tabular} & \begin{tabular}{l|l}
0,07 & 0 \\
\end{tabular} & \begin{tabular}{|l|l}
0,01 & 0 \\
\end{tabular} & \begin{tabular}{l|l}
0,01 & 0
\end{tabular} & \begin{tabular}{l|l}
0,17 & 0
\end{tabular} & \begin{tabular}{l|l}
0,01 & 0,
\end{tabular} & 0,190 & 0,15 & 0,010 & \begin{tabular}{|l|l}
0,03 & 0 \\
\end{tabular} & \begin{tabular}{|l|l}
0,01 & 0 \\
\end{tabular} & \begin{tabular}{|l|l}
0,48 & 0
\end{tabular} & \begin{tabular}{l|l}
0,01 & 0
\end{tabular} & \begin{tabular}{|l|l|l|}
0,01 & 0
\end{tabular} & \begin{tabular}{|l|l}
0,01 & 0 \\
\end{tabular} & \begin{tabular}{l|l}
0,01 & 0
\end{tabular} & 0,090 & 0,03 & 0,05 & 0,010 & 0,08 & 0,01 & 99 \\
\hline C17:0 & 0.01 & 0,01 & 0,01 & 0,01 & 0,15 & 0,19 & 0,01 & 0,51 & 0,12 & 0,01 & 0,12 & 0,01 & \begin{tabular}{|l|l}
0,310 \\
\end{tabular} & \begin{tabular}{l|l}
0,01 & 0
\end{tabular} & \begin{tabular}{l|l|l}
0,03 & 0
\end{tabular} & \begin{tabular}{l|l}
0,02 & 0
\end{tabular} & \begin{tabular}{l|l|l}
0,01 & 0
\end{tabular} & \begin{tabular}{l|l}
0,13 & 0 \\
\end{tabular} & \begin{tabular}{l|l}
0,32 & 0,
\end{tabular} & 0,080 & 0,33 & 0,01 & \begin{tabular}{|l|l|l}
0,03 & 0 \\
\end{tabular} & \begin{tabular}{|l|l}
0,19 & 0
\end{tabular} & 0,28 & 20 & \begin{tabular}{l|l}
0,31 & 1
\end{tabular} & \begin{tabular}{l|l|l}
1,12 & 0
\end{tabular} & \begin{tabular}{l|l|l}
0,02 & 0
\end{tabular} & 0,060 & 0,06 & 0,06 & \begin{tabular}{|l|l}
0,7 & 0 \\
\end{tabular} & 0,040 & 0,05 & 158 \\
\hline C18:3 & 1 & 0,01 & 0,01 & 0,01 & 0,01 & 0,01 & 0,01 & 0,01 & 0,01 & 0,01 & 0,01 & 0,01 & 0,010 & \begin{tabular}{l|l}
0,01 & 0 \\
\end{tabular} & \begin{tabular}{|l|l|l}
0,01 & 0 \\
\end{tabular} & \begin{tabular}{|l|l}
0,01 & 0 \\
\end{tabular} & \begin{tabular}{c|c}
0,01 & 0 \\
\end{tabular} & \begin{tabular}{l|l}
0,01 & 0
\end{tabular} & \begin{tabular}{l|l}
0,01 & 0,
\end{tabular} & 0,010 & 0,01 & 0,01 & \begin{tabular}{|l|l|}
0,01 & 0 \\
\end{tabular} & \begin{tabular}{|l|l|}
0,01 & 0 \\
\end{tabular} & \begin{tabular}{l|l}
0,01 & 0 \\
\end{tabular} & \begin{tabular}{l|l}
0,01 & 0 \\
\end{tabular} & \begin{tabular}{l|l}
0,01 & 0 \\
\end{tabular} & \begin{tabular}{l|l}
0,01 & 0 \\
\end{tabular} & \begin{tabular}{l|l}
0,01 & 0
\end{tabular} & $0,01 \quad 0$ & 0,010 & 0,01 & \begin{tabular}{|l|l}
0,01 & 0 \\
\end{tabular} & 0,010 & 0,01 & 0,01 \\
\hline C18:2n6 cis & 0 & 40,7 & 29,4 & 4,5 & 3,9 & 5,1 & 7,92 & 22,8 & 1,6 & 6,0 & 4,12 & 26,8 & \begin{tabular}{|l|}
3,9 \\
\end{tabular} & \begin{tabular}{l|l}
1,9 & 1 \\
\end{tabular} & \begin{tabular}{|l|l|}
10,6 & 8
\end{tabular} & \begin{tabular}{l|l}
8,4 & 1
\end{tabular} & \begin{tabular}{l|l}
13,5 & 1
\end{tabular} & \begin{tabular}{l|l}
12,5 & 3 \\
\end{tabular} & \begin{tabular}{l|l}
3,1 & 1
\end{tabular} & 11,4 & \begin{tabular}{l|l}
7,1 & 1
\end{tabular} & \begin{tabular}{|l|l}
10,5 & 4
\end{tabular} & 47,23 & \begin{tabular}{|l|l}
3,2 & 2
\end{tabular} & 2,15 & \begin{tabular}{l|l}
5,75 & 3 \\
\end{tabular} & 3,58 & \begin{tabular}{l|l}
6,9 & 0 \\
\end{tabular} & \begin{tabular}{l|l}
0,92 & 4
\end{tabular} & \begin{tabular}{l|l}
4,2 & 4
\end{tabular} & 40,9 & 47,0 & \begin{tabular}{l|l}
6,55 & 7
\end{tabular} & \begin{tabular}{|l|l|}
7,84 & 1
\end{tabular} & 14,7 & 3,3 \\
\hline $18: 1$ & & 40,7 & 52 & 70 & 74,5 & 55,4 & 82,0 & 22,87 & 75 & 56,3 & 79,24 & \begin{tabular}{|l|l}
48,9 & 3 \\
\end{tabular} & \begin{tabular}{|l|l}
37,3 & 9 \\
\end{tabular} & \begin{tabular}{l|l}
92,3 & 7 \\
\end{tabular} & \begin{tabular}{|l|l|}
79,9 & 8 \\
\end{tabular} & \begin{tabular}{l|l}
83,5 & 7 \\
\end{tabular} & \begin{tabular}{l|l}
71,8 & 6 \\
\end{tabular} & \begin{tabular}{l|l}
67,4 & 4 \\
\end{tabular} & \begin{tabular}{l|l}
42,2 & 73 \\
\end{tabular} & 72,03 & \begin{tabular}{|l|l}
35,3 & 2 \\
\end{tabular} & \begin{tabular}{|l|l}
26,2 & 4 \\
\end{tabular} & \begin{tabular}{|l|l|}
42,7 & 3 \\
\end{tabular} & \begin{tabular}{|l|l|}
33,8 & 6 \\
\end{tabular} & \begin{tabular}{ll|l}
67,4 & 2 \\
\end{tabular} & \begin{tabular}{|l|l}
22,7 & 2 \\
\end{tabular} & \begin{tabular}{|l|l}
28,0 & 3 \\
\end{tabular} & \begin{tabular}{|l|l}
37,4 & 9 \\
\end{tabular} & \begin{tabular}{l|l}
96,5 & 8 \\
\end{tabular} & 80,24 & \begin{tabular}{|l|l}
43,9 & 3 \\
\end{tabular} & 34,3 & \begin{tabular}{|l|l}
25,17 \\
\end{tabular} & 33 & 3 & \\
\hline C18:2 & 1 & 0,01 & 0,01 & 0,01 & 0,01 & 0,01 & 0,01 & $0,01 \mathrm{C}$ & $0,01 \mathrm{C}$ & 0,01 & $0,01 \mathrm{C}$ & 0,01 & \begin{tabular}{|l|l}
0,01 & 0
\end{tabular} & \begin{tabular}{l|l}
0,01 & 0
\end{tabular} & \begin{tabular}{l|l}
0,01 & 0
\end{tabular} & \begin{tabular}{l|l}
0,01 & 0
\end{tabular} & \begin{tabular}{l|l}
0,01 & 0
\end{tabular} & \begin{tabular}{l|l}
0,01 & 0
\end{tabular} & \begin{tabular}{l|l}
0,01 & 0,
\end{tabular} & 0,010 & \begin{tabular}{|l|l|}
0,01 & 0
\end{tabular} & \begin{tabular}{|l|l}
0,01 & 0
\end{tabular} & \begin{tabular}{|l|l}
0,01 & 0
\end{tabular} & \begin{tabular}{l|l}
0,01 & 0
\end{tabular} & \begin{tabular}{l|l}
0,01 & 0
\end{tabular} & \begin{tabular}{l|l}
0,01 & 0
\end{tabular} & \begin{tabular}{l|l}
0,01 & 0
\end{tabular} & \begin{tabular}{l|l}
0,01 & 0
\end{tabular} & \begin{tabular}{l|l}
0,01 & 0
\end{tabular} & 0,010 & $0,01 \mathrm{C}$ & 0,01 & \begin{tabular}{|l|l}
0,01 & 0
\end{tabular} & 0,01 & 0,01 &, 01 \\
\hline C18:1 & 0,01 & 0,01 & 0,01 & 0,01 & 0,01 & 0,01 & 0,01 & $0,01 \mathrm{C}$ & $0,01 \mathrm{C}$ & 0,01 & $0,01 \mathrm{C}$ & 0,01 & $0,01 \quad 0$ & \begin{tabular}{l|l}
0,01 & 0 \\
\end{tabular} & \begin{tabular}{l|l}
0,01 & 0 \\
\end{tabular} & $\begin{array}{lll}0,01 & 0\end{array}$ & $\begin{array}{ll}0,01 & 0\end{array}$ & $\begin{array}{ll}0,01 & 0\end{array}$ & 10 , & $0,01 \quad 0$ & 0,010 & \begin{tabular}{|l|l|}
0,01 & 0 \\
\end{tabular} & 10 & \begin{tabular}{|l|l|}
0,01 & 0 \\
\end{tabular} & \begin{tabular}{l|l}
0,01 & 0
\end{tabular} & $0,01 \quad 0$ & \begin{tabular}{l|l|l}
0,01 & 0
\end{tabular} & \begin{tabular}{l|l}
0,01 & 0
\end{tabular} & $0,01 \quad 0$ & $0,01 \quad 0$ & 0,010 & 0,01 & 010 & 0,01 & 0,01 & 01 \\
\hline C18:0 & 3,0 & 4,8 & 0,01 & 6,2 & 5,9 & 2,3 & 6 & 16,7 & 4,2 & 3,3 & 1,4 & 3,2 & 3,9 & 3,1 & 2,0 & 1,4 & \begin{tabular}{l|l}
$4,0 \quad 5$ \\
\end{tabular} & \begin{tabular}{l|l}
5,4 & 1 \\
\end{tabular} & $16,7 \quad 4$ & 4,9 & 2 & 0 & 2,8 & 24 & 4,9 & 21 & 14,2 & \begin{tabular}{l|l}
8,7 & 0 \\
\end{tabular} & \begin{tabular}{l|l}
0,23 & 1 \\
\end{tabular} & 1,4 & 2,5 & 3,7 & 12,2 & 6 & 8 & 41 \\
\hline C20:4 n6 & 0,01 & 0,01 & 0,01 & 0,01 & 0,01 & 0,01 & 0,01 & $0,01 \mathrm{C}$ & $0,01 \mathrm{C}$ & 0,01 & $0,01 \mathrm{C}$ & 0,01 & \begin{tabular}{|l|l}
0,01 & 0
\end{tabular} & \begin{tabular}{l|l}
0,01 & 0
\end{tabular} & \begin{tabular}{l|l}
0,01 & 0
\end{tabular} & \begin{tabular}{l|l}
0,01 & 0
\end{tabular} & \begin{tabular}{l|l}
0,01 & 0
\end{tabular} & \begin{tabular}{l|l}
0,01 & 0
\end{tabular} & \begin{tabular}{l|l}
0,01 & 0,
\end{tabular} & 0,010 & \begin{tabular}{|l|l|}
0,01 & 0 \\
\end{tabular} & \begin{tabular}{|l|l|}
0,01 & 0
\end{tabular} & \begin{tabular}{|l|l}
0,01 & 0
\end{tabular} & \begin{tabular}{|l|l|}
0,01 & 0
\end{tabular} & \begin{tabular}{l|l}
0,01 & 0
\end{tabular} & \begin{tabular}{l|l}
0,01 & 0
\end{tabular} & \begin{tabular}{l|l}
0,21 & 0
\end{tabular} & \begin{tabular}{l|l}
0,27 & 0
\end{tabular} & \begin{tabular}{l|l}
0,01 & 0
\end{tabular} & 0,010 & $0,01 \mathrm{C}$ & 0,01 & \begin{tabular}{|l|l}
0,01 & 0
\end{tabular} & 0,01 & & 02 \\
\hline C20:5 n3 & & 0,01 & 0,01 & 0,01 & 0,01 & 0,01 & 0,01 & $0,01 \mathrm{C}$ & $0,01 \mathrm{C}$ & 0,01 & $0,01 \mathrm{C}$ & 0,01 & $0,01 \quad 0$ & \begin{tabular}{l|l}
0,01 & 0
\end{tabular} & \begin{tabular}{l|l}
0,01 & 0 \\
\end{tabular} & \begin{tabular}{l|l}
0,01 & 0 \\
\end{tabular} & \begin{tabular}{l|l}
0,01 & 0 \\
\end{tabular} & \begin{tabular}{l|l}
0,01 & 0 \\
\end{tabular} & & 0,010 & \begin{tabular}{|l|l}
0,01 & 0 \\
\end{tabular} & \begin{tabular}{|l|l|}
0,01 & 0
\end{tabular} & & \begin{tabular}{|l|l}
0,01 & 0 \\
\end{tabular} & \begin{tabular}{l|l}
0,01 & 0 \\
\end{tabular} & \begin{tabular}{l|l}
0,01 & 0 \\
\end{tabular} & \begin{tabular}{l|l}
0,01 & 0 \\
\end{tabular} & \begin{tabular}{l|l}
0,01 & 0 \\
\end{tabular} & \begin{tabular}{l|l}
0,01 & 0
\end{tabular} & 0,010 & 0,010 & 0,01 & 10 & 0,01 & & \\
\hline $\mathrm{C} 20: 3 \mathrm{n} 3+\mathrm{n} 6$ & 0,01 & 0,01 & 0,01 & 0,01 & 0,01 & 0,01 & 0,01 & $0,01 \mathrm{C}$ & $0,01 \mathrm{C}$ & 0,01 & $0,01 \mathrm{C}$ & 0,010 & $0,01 \quad 0$ & \begin{tabular}{l|l}
0,01 & 0
\end{tabular} & \begin{tabular}{l|l}
0,01 & 0
\end{tabular} & \begin{tabular}{l|l}
0,01 & 0
\end{tabular} & \begin{tabular}{l|l}
0,01 & 0 \\
\end{tabular} & \begin{tabular}{l|l}
0,01 & 0
\end{tabular} & \begin{tabular}{l|l}
0,01 & 0,
\end{tabular} & 0,010 & \begin{tabular}{|l|l|}
0,01 & 0
\end{tabular} & \begin{tabular}{|l|l}
0,01 & 0
\end{tabular} & \begin{tabular}{l|l}
0,01 & 0
\end{tabular} & \begin{tabular}{l|l|l}
0,42 & 0 \\
\end{tabular} & \begin{tabular}{l|l}
0,01 & 0
\end{tabular} & 0,01 & \begin{tabular}{l|l}
0,1 & 0 \\
\end{tabular} & \begin{tabular}{l|l}
0,01 & 0
\end{tabular} & \begin{tabular}{l|l}
0,01 & 0
\end{tabular} & 0,010 & $0,01 \mathrm{C}$ & 0,01 & \begin{tabular}{|l|l}
0,01 & 0
\end{tabular} & 0,010 & 0,01 & 024 \\
\hline C20:2 n6 & 0,01 & 0,01 & 0,01 & 0,01 & 0,01 & 0,01 & 0,01 & $0,01 \mathrm{C}$ & $0,01 \mathrm{C}$ & 0,01 & $0,01 \mathrm{C}$ & 0,010 & 10 & \begin{tabular}{l|l}
0,01 & 0 \\
\end{tabular} & \begin{tabular}{l|l}
0,01 & 0 \\
\end{tabular} & \begin{tabular}{l|l}
0,01 & 0 \\
\end{tabular} & \begin{tabular}{l|l}
0,01 & 0 \\
\end{tabular} & \begin{tabular}{l|l}
0,01 & 0 \\
\end{tabular} & \begin{tabular}{l|l}
0,01 & 0,
\end{tabular} & 0,010 & \begin{tabular}{l|l}
0,01 & 0 \\
\end{tabular} & \begin{tabular}{|l|l|}
0,01 & 0 \\
\end{tabular} & \begin{tabular}{|l|l|}
0,01 & 0
\end{tabular} & \begin{tabular}{|l|l}
0,01 & 0 \\
\end{tabular} & \begin{tabular}{l|l}
0,01 & 0 \\
\end{tabular} & \begin{tabular}{l|l}
0,01 & 0 \\
\end{tabular} & \begin{tabular}{l|l}
0,01 & 0 \\
\end{tabular} & \begin{tabular}{l|l}
0,01 & 0 \\
\end{tabular} & \begin{tabular}{c|c}
0,01 & 0 \\
\end{tabular} & 0,010 & 0,010 & 0,01 & $\begin{array}{lll}01 & 0 \\
\end{array}$ & 01 & 01 & 01 \\
\hline C20:1 & & 0,01 & 0,01 & 0,01 & 0,97 & 0,47 & 0,012 & 2,09 & \begin{tabular}{|l|l}
0,7 & 0 \\
\end{tabular} & 0,01 & $0,01 \mathrm{C}$ & 0,36 & \begin{tabular}{|l|l}
0,01 \\
\end{tabular} & \begin{tabular}{l|l}
0,01 & 0 \\
\end{tabular} & \begin{tabular}{l|l}
0,49 & 0 \\
\end{tabular} & \begin{tabular}{l|l}
0,01 & 0 \\
\end{tabular} & \begin{tabular}{l|l}
0,01 & 0
\end{tabular} & \begin{tabular}{l|l}
0,73 & 0
\end{tabular} & $\begin{array}{ll}0,01 & 0,\end{array}$ & \begin{tabular}{l|l}
0,01 & 0
\end{tabular} & \begin{tabular}{|l|l}
0,01 & 0
\end{tabular} & \begin{tabular}{|l|l}
0,01 & 0
\end{tabular} & \begin{tabular}{|l|l}
0,01 & 0
\end{tabular} & \begin{tabular}{|l|l}
0,01 & 0,
\end{tabular} & \begin{tabular}{l|l}
0,01 & 0 \\
\end{tabular} & \begin{tabular}{l|l}
0,01 & 0 \\
\end{tabular} & 0,01 & \begin{tabular}{l|l}
1,6 & 0 \\
\end{tabular} & \begin{tabular}{l|l}
0,01 \\
\end{tabular} & \begin{tabular}{l|l}
1,7 & 0
\end{tabular} & 0,49 & 0,08 & \begin{tabular}{|l|l}
0,01 & 0
\end{tabular} & 0,85 & 0,01 & 307 \\
\hline C20:0 & 0,59 & 0,18 & 0,01 & 0,01 & 0,98 & 0,66 & \begin{tabular}{|l|}
0,29 \\
\end{tabular} & \begin{tabular}{|l|l|l|}
2,9 & 0
\end{tabular} & \begin{tabular}{l|l}
0,910 \\
\end{tabular} & 0,01 & 1,9 & 0,4 & \begin{tabular}{|l|l|l|}
0,99 \\
\end{tabular} & \begin{tabular}{l|l}
0,01 & 0
\end{tabular} & \begin{tabular}{l|l}
0,59 & 0 \\
\end{tabular} & \begin{tabular}{|l|l}
0,96 & 0
\end{tabular} & \begin{tabular}{l|l}
0,41 & 0
\end{tabular} & \begin{tabular}{r|r}
0,88 & 0
\end{tabular} & \begin{tabular}{l|l}
0,25 & 0,
\end{tabular} & 0,43 & \begin{tabular}{|l|l|l|l|}
1,0 & 0 \\
\end{tabular} & \begin{tabular}{|l|l}
0,01 & 0
\end{tabular} & \begin{tabular}{l|l}
0,22 & 1
\end{tabular} & \begin{tabular}{l|l}
1,1 & 0
\end{tabular} & \begin{tabular}{|l|l}
0,45 & 0
\end{tabular} & \begin{tabular}{|l|l|l|}
0,24 & 0
\end{tabular} & 0,39 & \begin{tabular}{|l|l}
4,6 & 0
\end{tabular} & 0,45 & 1,7 & 1,2 & 0,11 & \begin{tabular}{|l|l}
0,19 & 0
\end{tabular} & 0,96 & 0,17 & 746 \\
\hline C21:0 & ${ }^{1}$ & 0,01 & 0,01 & 0,01 & 0,05 & 0,01 & 0,01 & 0,01 & \begin{tabular}{l|l}
0,01 & 0
\end{tabular} & 0,01 & 0,01 & 0,01 & 0,01 & \begin{tabular}{l|l}
0,01 & 0
\end{tabular} & \begin{tabular}{|l|l}
0,01 & 0 \\
\end{tabular} & \begin{tabular}{l|l}
0,01 & 0 \\
\end{tabular} & \begin{tabular}{l|l}
0,01 & 0
\end{tabular} & \begin{tabular}{l|l}
0,01 & 0
\end{tabular} & \begin{tabular}{l|l}
0,01 & 0,
\end{tabular} & \begin{tabular}{l|l}
0,01 & 0
\end{tabular} & \begin{tabular}{|l|l}
0,01 & 0 \\
\end{tabular} & \begin{tabular}{|l|l}
0,01 & 0 \\
\end{tabular} & \begin{tabular}{|l|l}
0,01 & 0
\end{tabular} & \begin{tabular}{|l|l}
0,06 & 0,
\end{tabular} & \begin{tabular}{l|l}
0,01 & 0 \\
\end{tabular} & \begin{tabular}{l|l}
0,01 & 0
\end{tabular} & \begin{tabular}{|l|l}
0,01 & 0 \\
\end{tabular} & \begin{tabular}{l|l}
0,01 & 0 \\
\end{tabular} & \begin{tabular}{l|l}
0,01 & 0
\end{tabular} & \begin{tabular}{l|l}
0,01 & 0
\end{tabular} & 0,01 & 0,01 & 0,010 & 0,01 & 0,01 & 013 \\
\hline C22:6 & 0,01 & 0,01 & 0,01 & 0,01 & 0,01 & 0,01 & \begin{tabular}{|l|l|l|}
0,01 & 0
\end{tabular} & \begin{tabular}{|l|l|l|l|}
0,01 & 0
\end{tabular} & \begin{tabular}{l|l}
0,01 & 0
\end{tabular} & 0,01 & 0,01 & \begin{tabular}{|l|l|l|}
0,01 & 0
\end{tabular} & \begin{tabular}{|l|l|l|l|}
0,01 & 0
\end{tabular} & \begin{tabular}{l|l}
0,01 & 0
\end{tabular} & \begin{tabular}{l|l}
0,01 & 0
\end{tabular} & \begin{tabular}{|l|l|l}
0,01 & 0
\end{tabular} & \begin{tabular}{l|l|l}
0,01 & 0
\end{tabular} & \begin{tabular}{l|l}
0,01 & 0
\end{tabular} & \begin{tabular}{l|l}
0,01 & 0,
\end{tabular} & \begin{tabular}{l|l}
0,01 & 0
\end{tabular} & \begin{tabular}{|l|l|l|l|}
0,01 & 0
\end{tabular} & \begin{tabular}{|l|l|l|l|}
0,01 & 0
\end{tabular} & \begin{tabular}{l|l}
0,01 & 0
\end{tabular} & \begin{tabular}{|c|c}
0,03 & 0,
\end{tabular} & \begin{tabular}{l|l}
0,03 & 0
\end{tabular} & \begin{tabular}{l|l}
0,01 & 0
\end{tabular} & \begin{tabular}{l|l}
0,07 & 0
\end{tabular} & \begin{tabular}{l|l}
0,01 & 0
\end{tabular} & \begin{tabular}{l|l}
0,01 & 0
\end{tabular} & \begin{tabular}{l|l}
0,01 & 0
\end{tabular} & 0,01 & 0,01 & \begin{tabular}{|l|l|l|l|}
0,01 & 0
\end{tabular} & 0,01 & 0,01 & 013 \\
\hline C22:2 & 0 , & 0,01 & 0,01 & 0,01 & 0,01 & 0,01 & 0,01 & 0,010 & 0,010 & 0,01 & 0,01 & 0,01 & & \begin{tabular}{l|l}
0,01 & 0
\end{tabular} & \begin{tabular}{l|l}
0,01 & 0
\end{tabular} & \begin{tabular}{l|l}
0,01 & 0
\end{tabular} & \begin{tabular}{l|l}
0,01 & 0
\end{tabular} & \begin{tabular}{l|l}
0,01 & 0
\end{tabular} & & & \begin{tabular}{|l|l}
0,01 & 0
\end{tabular} & \begin{tabular}{|l|l}
0,01 & 0
\end{tabular} & & \begin{tabular}{l|l}
0,01 & 0,
\end{tabular} & \begin{tabular}{l|l}
0,01 & 0
\end{tabular} & 0,010 & \begin{tabular}{l|l}
0,01 & 0
\end{tabular} & \begin{tabular}{l|l}
0,01 & 0
\end{tabular} & \begin{tabular}{l|l}
0,01 & 0
\end{tabular} & 0,010 & 0,01 & 0,01 & 010 & 0,01 & 01 & \\
\hline $\mathrm{C} 22: 1 \mathrm{n}$ & 0, & 0,01 & 0,01 & 0,01 & 0,01 & 0,01 & 0,01 & 0,01 & \begin{tabular}{l|l}
0,01 & 0
\end{tabular} & 0,01 & 0,01 & 0,01 & 0,010 & \begin{tabular}{l|l}
0,01 & 0 \\
\end{tabular} & \begin{tabular}{|l|l|l}
0,01 & 0 \\
\end{tabular} & \begin{tabular}{|l|l}
0,01 & 0 \\
\end{tabular} & \begin{tabular}{c|c}
0,01 & 0 \\
\end{tabular} & \begin{tabular}{l|l}
0,01 & 0
\end{tabular} & \begin{tabular}{l|l}
0,01 & 0,
\end{tabular} & \begin{tabular}{l|l}
0,01 & 0
\end{tabular} & \begin{tabular}{|l|l}
0,01 & 0 \\
\end{tabular} & \begin{tabular}{|l|l|l|}
0,01 & 0
\end{tabular} & \begin{tabular}{|l|l}
0,01 & 0
\end{tabular} & \begin{tabular}{|l|l}
0,01 & 0,
\end{tabular} & \begin{tabular}{l|l}
0,01 & 0
\end{tabular} & \begin{tabular}{l|l}
0,01 & 0
\end{tabular} & \begin{tabular}{|l|l}
0,01 & 0 \\
\end{tabular} & \begin{tabular}{l|l}
0,01 & 0 \\
\end{tabular} & \begin{tabular}{l|l}
0,01 & 0
\end{tabular} & \begin{tabular}{l|l}
0,01 & 0
\end{tabular} & 0,01 & 0,01 & \begin{tabular}{|l|l}
0,01 & 0
\end{tabular} & 0,01 & 0,01 & 1 \\
\hline C22:0 & 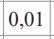 & 0,01 & 0,01 & 0,01 & 0,51 & 0,27 & \begin{tabular}{|l|l|}
0,73 \\
\end{tabular} & \begin{tabular}{|l|l|l|}
0,58 & 0
\end{tabular} & 0,360 & 0,01 & 2,8 & 0,01 & 0,070 & 0,01 & 1,1 & \begin{tabular}{l|l}
2,9 & 0
\end{tabular} & \begin{tabular}{l|l}
0,31 & 0
\end{tabular} & \begin{tabular}{c|c}
0,81 & 0
\end{tabular} & \begin{tabular}{l|l|l}
0,16 & 0,
\end{tabular} & \begin{tabular}{l|l}
0,62 & 0
\end{tabular} & \begin{tabular}{|l|l}
0,34 & 0 \\
\end{tabular} & \begin{tabular}{|l|l}
0,01 & 0 \\
\end{tabular} & \begin{tabular}{|l|l}
0,49 & 0
\end{tabular} & \begin{tabular}{|l|l}
0,42 & 0
\end{tabular} & \begin{tabular}{l|l}
0,9 & 0
\end{tabular} & \begin{tabular}{|l|l}
0,18 & 0
\end{tabular} & 0,09 & \begin{tabular}{l|l}
0,9 & 0
\end{tabular} & \begin{tabular}{l|l}
0,65 & 4
\end{tabular} & 4,8 & 1,4 & 0,24 & 2,9 & 8,9 & 0,01 & 87 \\
\hline $\mathrm{C} 23$ & & 0,01 & 0,01 & 0,01 & 0,01 & 0,01 & \begin{tabular}{|l|l}
0,01 & 0
\end{tabular} & 0,05 & \begin{tabular}{l|l}
0,12 & 0
\end{tabular} & 0,01 & 0,07 & 0,010 & 0,010 & \begin{tabular}{l|l}
0,01 & 0
\end{tabular} & \begin{tabular}{l|l}
0,01 & 0
\end{tabular} & \begin{tabular}{l|l}
0,01 & 0
\end{tabular} & \begin{tabular}{l|l}
0,01 & 0
\end{tabular} & \begin{tabular}{l|l}
0,01 & 0
\end{tabular} & \begin{tabular}{l|l}
0,01 & 0,
\end{tabular} & \begin{tabular}{l|l}
0,01 & 0 \\
\end{tabular} & \begin{tabular}{|l|l}
0,01 & 0
\end{tabular} & \begin{tabular}{|l|l|l}
0,01 & 0 \\
\end{tabular} & \begin{tabular}{l|l}
0,02 & 0
\end{tabular} & \begin{tabular}{l|l}
0,04 & 0,
\end{tabular} & \begin{tabular}{l|l}
0,01 & 0
\end{tabular} & \begin{tabular}{l|l}
$0,01 \quad 0$ \\
\end{tabular} & 0,02 & \begin{tabular}{l|l}
0,7 & 0
\end{tabular} & \begin{tabular}{l|l}
0,01 & 0
\end{tabular} & \begin{tabular}{l|l}
0,07 & 0
\end{tabular} & 0,01 & 0,16 & 0,010 & 0,01 & 0,01 & ,043 \\
\hline C24:0 & 0,01 & 0,01 & 0,01 & 0,01 & 0,01 & 0,01 & \begin{tabular}{|l|l}
0,01 & 0
\end{tabular} & 0,170 & \begin{tabular}{l|l}
0,01 & 0
\end{tabular} & 0,01 & 0,8 & \begin{tabular}{|l|}
0,01 \\
\end{tabular} & \begin{tabular}{|l|l|l|}
0,2 & 0
\end{tabular} & \begin{tabular}{l|l}
0,01 & 0
\end{tabular} & \begin{tabular}{|l|l|l}
0,34 & 0
\end{tabular} & \begin{tabular}{|l|l}
0,52 & 0
\end{tabular} & \begin{tabular}{l|l}
0,07 & 0
\end{tabular} & \begin{tabular}{l|l}
0,28 & 0
\end{tabular} & \begin{tabular}{l|l}
0,01 & 0,
\end{tabular} & \begin{tabular}{l|l}
0,01 & 0
\end{tabular} & \begin{tabular}{|l|l|l|l|}
0,01 & 0
\end{tabular} & \begin{tabular}{|l|l}
0,01 & 0
\end{tabular} & \begin{tabular}{l|l}
0,11 & 0
\end{tabular} & \begin{tabular}{l|l}
0,12 & 0
\end{tabular} & \begin{tabular}{l|l}
0,3 & 0 \\
\end{tabular} & \begin{tabular}{l|l}
0,01 & 0
\end{tabular} & \begin{tabular}{|l|l|l}
0,06 & 0
\end{tabular} & \begin{tabular}{|l|l}
0,55 & 0
\end{tabular} & \begin{tabular}{l|l}
0,01 & 1
\end{tabular} & 1,01 & 0,2 & 1,24 & 0,01 & 0,6 & 0,01 & 0,193 \\
\hline $24: 1$ & ,01 & 0,01 & 0,01 & 0,01 & 0,01 & 0,01 & 0,010 & 0,010 & 0,010 & 0,01 & 0,01 & \begin{tabular}{|l|l|}
0,01 & 0
\end{tabular} & 0,010 & \begin{tabular}{l|l}
0,01 & 0
\end{tabular} & \begin{tabular}{l|l}
0,01 & 0
\end{tabular} & \begin{tabular}{l|l}
0,01 & 0
\end{tabular} & \begin{tabular}{l|l}
0,01 & 0
\end{tabular} & \begin{tabular}{l|l}
0,01 & 0
\end{tabular} & \begin{tabular}{l|l}
0,01 & 0,
\end{tabular} & \begin{tabular}{l|l}
0,01 & 0
\end{tabular} & \begin{tabular}{|l|l|l|l|}
0,01 & 0
\end{tabular} & \begin{tabular}{|l|l}
0,01 & 0
\end{tabular} & \begin{tabular}{l|l}
0,01 & 0
\end{tabular} & \begin{tabular}{l|l}
0,01 & 0
\end{tabular} & \begin{tabular}{l|l}
0,01 & 0
\end{tabular} & \begin{tabular}{l|l}
0,01 & 0
\end{tabular} & \begin{tabular}{l|l}
0,01 & 0
\end{tabular} & \begin{tabular}{l|l}
0,01 & 0
\end{tabular} & \begin{tabular}{l|l}
0,01 & 0
\end{tabular} & \begin{tabular}{l|l}
0,01 & 0
\end{tabular} & 0,01 & 0,01 & \begin{tabular}{|l|l|l|l}
0,01 & 0
\end{tabular} & 0,01 & 0,01 & 0,01 \\
\hline
\end{tabular}

\section{Conclusions}

Most of the nutritional data reported in literature, are based on food labels. Few data were obtained by direct chemical analysis of food. In this context, will be necessary to encourage the use of chemical analytical practices in order to provide doctors and nutritionists the necessary data to compile balanced diets for users of gluten-free products and to determine their contribution to the daily intake of nutrients and micro elements. Special emphasis has been addressed to metal contents, fatty acid profiles and fibers.

Literature analysis has highlighted that, the most gluten free food, show a deficit of nutrients in term of concentrations. At this regard, an inadequate nutritional value of the GF-diet was observed from several authors. In detail, it was founded nutrient deficiencies for essential minerals such as iron, zinc magnesium and calcium, and on another hand high content of saturated lipids were detected.

Furthermore, the dietary-therapeutic approach should encourage the use of naturally gluten free products such as pseudo-cereals and fruits concerning to metal contents, and fish or seafood regarding fatty acids, especially for sutured and unsatured fatty acid ratio.

Moreover, alimentary education should become part of the therapeutic pathway to understand the importance of labels, choice of food and combination of macro and micronutrients.

\section{Acknowledgments}

This study was made possible by the financial support of Palermo university that has funded the author (Grants 2018).

\section{References}

1. Fasano A (2003) European and North American populations should be screened for coeliac disease. Gut 52: 168-169. [Crossref]

2. Villalta D, Tonutti E, Prause C, Koletzko S, Uhlig HH, et al. (2010) IgG antibodies against deamidated gliadin peptides for diagnosis of celiac disease in patients with IgA deficiency. Clin Chem 56: 464-468. [Crossref]

3. Pender SLF, Lionetti P, Murch SH, Wathan N, MacDonald TT (1996) Proteolytic degradation of intestinal mucosa extracellular matrix after lamina propria $\mathrm{T}$ cell activation. Gut 39: 284-290. [Crossref]

4. Wierdsma NJ, van Bokhorst-de van der Schueren M, Berkenpas M, Mulder CJ, van Bodegraven AA (2013) Vitamin and mineral deficiencies are highly prevalent in newly diagnosed celiac disease patients. Nutrients 5: 3975-3992. [Crossref]

5. Ciacci C, Ciclitira P, Hadjivassiliou M, Kaukinen K, Ludvigsson JF, et al. (2015) The gluten-free diet and its current application in coeliac disease and dermatitis herpetiformis. United European Gastroenterol J 3: 121-135. [Crossref]

6. De Simas KN, Vieira LDN, Podestá R, Müller CM, Vieira MA, et al. (2009) Effect of king palm (Archontophoenix alexandrae) flour incorporation on physicochemical and textural characteristics of gluten-free cookies. Int J Food Sci Technol 44: 531-538.

7. Maggio A, Orecchio S (2018) Fatty acid composition of gluten-free food (bakery products) for celiac people. Foods 7. [Crossref]

8. Segura MEM, Rosell CM (2011) Chemical composition and starch digestibility of different gluten-free breads. Plant Foods Hum Nutr 66: 224. [Crossref] 
9. Curiel JA, Coda R, Limitone A, Katina K, Raulio M, et al. (2014) Manufacture and characterization of pasta made with wheat flour rendered gluten-free using fungal proteases and selected sourdough lactic acid bacteria. J Cereal Sci 59: 79-87.

10. Alvarez-Jubete L, Arendt EK, Gallagher E (2009) Nutritive value and chemical composition of pseudocereals as gluten-free ingredients. Int J Food Sci Nutr 60: 240257.

11. Wild D, Robins GG, Burley VJ, Howdle PD (2010) Evidence of high sugar intake, and low fibre and mineral intake, in the gluten-free diet. Aliment Pharmacol Ther 32: 573-581. [Crossref]

12. Tsikritzi R, Moynihan PJ, Gosney MA, Allen VJ, Methven L (2014) The effect of macro and micronutrient fortification of biscuits on their sensory properties and on hedonic liking of older people. J Sci Food Agric 94: 2040-2048. [Crossref]

13. Jason Wu HY, Neal B, Trevena H, Crino M, Stuart-Smith W, et al. (2015) Are glutenfree foods healthier than non-gluten-free foods? An evaluation of supermarket products in Australia. Br J Nutr 114: 448-454. [Crossref]

14. Bardella MT, Fredella C, Prampolini L, Molteni N, Giunta AM, et al. (2000) Body composition and dietary intakes in adult celiac disease patients consuming a strict gluten-free diet. Am J Clin Nutr 72: 937-939. [Crossref]

15. Mariani P, Viti MG, Montuori M, La Vecchia A, Cipolletta E, et al. (1998) The gluten-free diet: a nutritional risk factor for adolescents with celiac disease? J Pediatr Gastroenterol Nutr 27: 519-523. [Crossref]

16. Thompson T, Dennis M, Higgins LA, Lee AR, Sharrett MK (2005) Gluten-free diet survey: are Americans with celiac disease consuming recommended amounts of fibre, iron, calcium and grain foods? J Hum Nutr Diet 18: 163-169. [Crossref]

17. Hopman EG, le Cessie S, von Blomberg BM, Mearin ML (2006) Nutritional management of the gluten-free diet in young people with celiac disease in The Netherlands. J Pediatr Gastroenterol Nutr 43: 102-108. [Crossref]

18. Bourekoua H, Benatallah L, Nasreddine Zidoune M, Rosell CM (2016) Developing gluten free bakery improvers by hydrothermal treatment of rice and corn flours. Food Sci Tech 73: 342-350.

19. Alvarez-Jubete L, Arendt EK, Gallagher E (2010) Nutritive value of pseudocereals and their increasing use as functional gluten free ingredients. Trends Food Sci Technol 21: 106-113.

20. Koziol MJ (1992) Chemical composition and nutritional evaluation of quinoa (Chenopodium quinoa Willd.). J Food Compost Anal 5: 35-68.

21. Bressani R (1994) Composition and nutritional properties of amaranth. In: ParedesLopez O (Ed.), Amaranth-biology, chemistry and technology. CRC Press Inc, London.

22. Alvarez-Jubete L, Arendt EK, Gallagher E (2009) Nutritive value and chemical composition of pseudocereals as gluten-free ingredients. Int J Food Sci Nutr 60: 240257. [Crossref]

23. Zhu F (2018) Chemical composition and food uses of teff (Eragrostis tef). Food Chem 239: 402-415. [Crossref]

24. Gebremariam MM, Zarnkow M, Becker T (2014) Teff (Eragrostis tef) as a raw material for malting, brewing and manufacturing of gluten-free foods and beverages: a review. $J$ Food Sci Technol 51: 2881-2895. [Crossref]

25. Shumoy H, Raes K (2016) Antioxidant potentials and phenolic composition of tef varieties: An indigenous Ethiopian cereal. Cereal Chem 93: 465-470.

26. Barreca S, Orecchio S, Pace A (2013) Photochemical sample treatment for extracts clean up in PCB analysis from sediments. Talanta 103: 349-354. [Crossref]

27. Barreca S, Mazzola A, Orecchio S, Tuzzolino N (2014) Polychlorinated biphenyls in sediments from sicilian coastal area (Scoglitti) using automated soxhlet, GC-MS, and principal component analysis. Polycyclic Aromatic Compounds 34: 237-262.

28. Ahmad Mir N, Singh Riar C, Singh S (2018) Nutritional constituents of pseudo cereals and their potential use in food systems: A review. Trends Food Sci Technol 75: 170-180.

29. Jancurovà M, Minarovicovà L, Dandar A (2009) Quinoa - A review. Czech J Food Sci 27: 71-79.

30. Valencia-Chamorro SA (2003) Quinoa. In: Caballero B (Vol. Ed.), Encyclopedia of food science and nutrition. Encyclopedia of food science and nutrition, Academic press, Amsterdam, pp: 4895-4902.

31. Jan KN, Panesar PS, Rana JC, Singh S (2017) Structural, thermal and rheological properties of starches isolated from Indian quinoa varieties. Int J Biol Macromol 102: 315-322.
32. Orecchio S, Amorello D, Raso M, Barreca S, Lino C, et al. (2014) Determination of trace elements in gluten-free food for celiac people by ICP-MS. Microchem $J 116$ : $163-172$.

33. Amorello D, Orecchio S, Pace A, Barreca S (2015) Discrimination of almonds (Prunus dulcis) geographical origin by minerals and fatty acids profiling. Short communications. Nat Prod Res 30: 2107-2110. [Crossref]

34. Ali Zounr, R Tuzen M, Yar Khuhawar M (2018) A simple and green deep eutectic solvent based air assisted liquid phase microextraction for separation, preconcentration and determination of lead in water and food samples by graphite furnace atomic absorption spectrometry. J Mol Liq 259: 220-22.

35. Amorello D, Barreca S, Gulli E, Orecchio S (2017) Platinum and Rhodium in wine samples by using voltammetric techniques. Microchem J 130: 229-235.

36. Soetan KO, Olaiya CO, Oyewole OE (2010) The importance of mineral elements for humans, domestic animals and plants: a review. Afr J Food Sci 4: 200-222.

37. Steadman KJ, Burgoon MS, Lewis BA, Edwardson SE, Obendorf RL (2001) Buckwheat seed milling fractions: Description, macronutrient composition and dietary fibre. J Cereal Sci 33: 271-278.

38. Baye K, Mouquet-Rivier C, Icard-Vernière C, Picq C, Guyot JP (2014) Changes in mineral absorption inhibitors consequent to fermentation of Ethiopian injera: Implications for predicted iron bioavailability and bioaccessibility. Int J Food Sci Technol 49: 174-180.

39. Orecchio S, Amorello D, Raso M, Barreca S, Lino C, et al. (2015) Determination of macro elements in gluten-free food for celiac people by ICP-OES. Life Saf Secur 3 : $36-48$.

40. Commission Regulation (EC) No 1881/2006 of 19 December 2006 (2006) Setting maximum levels for certain contaminants in foodstuffs. Off $J$ Eur Union L364: 00050024, 2006.

41. González-Weller D, Rubio C, Gutiérrez AJ, González GL, Caballero Mesa JM, et al. (2013) Dietary intake of barium, bismuth, chromium, lithium, and strontium in a Spanish population (Canary Islands, Spain). Food Chem Toxicol 62: 856-868. [Crossref]

42. Rubio Armendáriz C, Gonzalez-Weller D, Gutierrez Fernandez AJ, Hardisson De La Torre A (2010) Levels of lithium in the six most taken groups of food among the Canarian population. Abstracts /Toxicol Lett 196S: S37-S351.

43. Rodriguez LH, Morales DA, Rodrıguez RE, Romero CD (2011) Minerals and trace elements in a collection of wheat landraces from the Canary Islands. Food Comp Anal 24: 1081-1090.

44. Pedron T, Segura FR, da Silva FF, de Souza AL, Maltez HF, et al. (2016) Essential and non-essential elements in Brazilian infant food and other rice-based products frequently consumed by children and celiac population. J Food Compost Anal 49: 78-86.

45. Škrbić B, Živančev J, Mrmoš N (2013) Concentrations of arsenic, cadmium and lead in selected foodstuffs from Serbian market basket: estimated intake by the population from the Serbia. Food Chem Toxicol 58: 440-448. [Crossref]

46. FAO/WHO (2007) Food Balance Sheet. faostat.fao.org/site/368/default.aspx\#ancor.

47. Usydus Z, Szlinder-Richert J, Polak-Juszczak L, Komar K, Adamczyk M, et al (2009) Fish products available in Polish market--assessment of the nutritive value and human exposure to dioxins and other contaminants. Chemosphere 74: 14201428. [Crossref]

48. EFSA (European Food Safety Authority), EFSA panel on contaminants in the food chain (CONTAM) (1999) Scientific opinion on arsenic in food. EFSA J 7: 1351.

49. EFSA (European Food Safety Authority), EFSA panel on contaminants in the food chain (CONTAM) (2010) Scientific opinion on lead in food. EFSA J 8: 1570

50. Munera-Picazo S, Burló F, Carbonell-Barrachina AA (2014) Arsenic speciation in rice-based food for adults with celiac disease. Food Addit Contam Part A Chem Anal Control Expo Risk Assess 31: 1358-1366.

51. Forsido SF, Rupasinghe HPV, Astatkie T (2013) Antioxidant capacity, total phenolics and nutritional content in selected Ethiopian staple food ingredients. Int J Food Sc Nutr 64: 915-920.

52. Rayman MP, Infante HG, Sargent M (2008) Food-chain selenium and human health: Spotlight on speciation. Br J Nutr 100: 238-253.

53. Punshon T, Jackson BP (2018) Essential micronutrient and toxic trace element concentrations in gluten containing and gluten-free foods. Food Chem 252: 258-264 [Crossref]

54. Carbonell-Barrachina AA, Wu X, Ramirez-Gandolfo A, Norton GJ, Burlo F, et al (2012) Inorganic arsenic contents in rice-based infant foods from Spain, UK, China and USA. Environ Pollut 163: 77-83. [Crossref] 
55. Greger JL (1985) Aluminium content of the American diet. Food Technol 39: 73-74.

56. López FE, Cabrera C, Lorenzo ML, López MC (2002) Aluminum levels in convenience and fast foods: in vitro study of the absorbable fraction. Sci Total Environ 300: 69-79. [Crossref]

57. Yokel RA, Urbas AA, Lodder RA, Selegue JP, Florence RL (2005) Al-containing acidic and basic sodium aluminum phosphate preparation and use in studies of oral aluminum bioavailability from foods utilizing 26Al as an aluminum tracer. Nucl Instr Meth Physics Res Sec B 229: 471-478.

58. Loska K, Wiechuya D (2003) Application of principle component analysis for the estimation of source of heavy metal contamination in surface sediments from the Rybnik reservoir. Chemosphere 51: 723-733.

59. Bonafaccia G, Marocchini M, Kreft I (2003) Composition and technological properties of the flour and bran from common and tartary buckwheat. Food Chem 80: 9e15.

60. Bruni R, Medici A, Guerrini A, Scalia S, Poli F, et al. (2001) Wild Amaranthus caudatus seed oil, a nutraceutical resource from Ecuadorian flora. J Agric Food Chem 49: 5455 5460 .
61. Ruales J, Nair BM (1993) Content of fat, vitamins and minerals in quinoa (Chenopodium quinoa, Willd) seeds. Food Chem 48: 131-136.

62. Simopoulos AP (2001) Evolutionary aspects of diet, the omega-6/omega-3 ratio and genetic variation: nutritional implications for chronic diseases. Biomed Pharmacother 60: 502-507. [Crossref]

63. Hager AS, Wolter A, Jacob F, Zannini E, Arendt EK (2012) Nutritional properties and ultra-structure of commercial gluten free flours from different botanical sources compared to wheat flours. J Cereal Sci 56: 239-247. [Crossref]

64. European Food Safety Authority. http://www.efsa.europa.eu/it. Accessed on October $2,2018$.

65. Gonçalves Albuquerquea T, Santos J, Beatriz MASM, Oliveira PP, Costa HS (2018) An update on processed foods: Relationship between salt, saturated and trans fatty acids contents. Food Chem 267: 75-82.

66. Mancebo MC, San Miguel MA, Martínez MM, Gomez M (2015) Optimisation of rheological properties of gluten-free doughs with HPMC, psyllium and different levels of water. J Cereal Sci 61: 8-15.

Copyright: (C2019 Maggio A. This is an open-access article distributed under the terms of the Creative Commons Attribution License, which permits unrestricted use, distribution, and reproduction in any medium, provided the original author and source are credited. 